Louisiana State University

LSU Digital Commons

Faculty Publications

Department of Biological Sciences

$1-1-2017$

\title{
A New Species and Introgression in Eastern Asian Hemlocks (Pinaceae: Tsuga)
}

\author{
Garth Holman \\ University of Maine \\ Peter Del Tredici \\ Harvard University \\ Nathan Havill \\ USDA Forest Service \\ Nam Sook Lee \\ Ewha Womans University \\ Richard Cronn \\ USDA ARS Corvallis Forestry Sciences Laboratory
}

See next page for additional authors

Follow this and additional works at: https://digitalcommons.Isu.edu/biosci_pubs

\section{Recommended Citation}

Holman, G., Tredici, P., Havill, N., Lee, N., Cronn, R., Cushman, K., Mathews, S., Raubeson, L., \& Campbell, C. (2017). A New Species and Introgression in Eastern Asian Hemlocks (Pinaceae: Tsuga). Systematic Botany, 42 (4) https://doi.org/10.1600/036364417X696474

This Article is brought to you for free and open access by the Department of Biological Sciences at LSU Digital Commons. It has been accepted for inclusion in Faculty Publications by an authorized administrator of LSU Digital Commons. For more information, please contact ir@lsu.edu. 


\section{Authors}

Garth Holman, Peter Del Tredici, Nathan Havill, Nam Sook Lee, Richard Cronn, Kevin Cushman, Sarah Mathews, Linda Raubeson, and Christopher S. Campbell 
Systematic Botany (2017), 42(4): pp. 733-746

(c) Copyright 2017 by the American Society of Plant Taxonomists

DOI 10.1600/036364417X696474

Date of publication December 18, 2017

\title{
A New Species and Introgression in Eastern Asian Hemlocks (Pinaceae: Tsuga)
}

\author{
Garth Holman, ${ }^{1,9}$ Peter Del Tredici, ${ }^{2}$ Nathan Havill, ${ }^{3}$ Nam Sook Lee, ${ }^{4}$ Richard Cronn, ${ }^{5}$ Kevin Cushman, ${ }^{6}$ \\ Sarah Mathews, ${ }^{7}$ Linda Raubeson, ${ }^{8}$ and Christopher S. Campbell ${ }^{1}$ \\ ${ }^{\mathbf{1}}$ School of Biology and Ecology, University of Maine, Orono, Maine 04469, U. S. A. \\ ${ }^{2}$ Arnold Arboretum, 125 Arborway, Boston, Massachusetts 02130-3519, U. S. A. \\ ${ }^{3}$ USDA Forest Service, Northern Research Station, 51 Mill Pond Rd., Hamden, Connecticut 06514, U. S. A. \\ ${ }^{4}$ Ewha Womans University, Department of Life Sciences, Seoul, 120-750, Korea \\ ${ }^{5}$ Pacific Northwest Research Station, USDA Forest Service, Corvallis, Oregon 97331, U. S. A. \\ ${ }^{6}$ Department of Plant and Soil Science, Texas Tech University, Lubbock, Texas 79409, U. S. A. \\ ${ }^{7}$ CSIRO National Research Collections Australia, Australian National Herbarium, Canberra, ACT 2601, Australia \\ ${ }^{8}$ Department of Biological Sciences, Central Washington University, Ellensburg, Washington 98926, U. S. A. \\ ${ }^{9}$ Author for correspondence (garth.holman@maine.edu)
}

\section{Communicating Editor: Min Feng}

\begin{abstract}
Species delimitation in Pinaceae is often challenged by limited morphological differentiation and introgression. In Tsuga (hemlocks), species delimitation has been most challenging among northeastern Asian taxa, where the species are weakly marked morphologically and range in number from three to five in previous studies. Two low-copy nuclear four-coumarase-ligase (4CL) genes and morphology strongly support a clade of the Japanese endemic T. diversifolia and T. sieboldii from Japan and Ulleung island (Ulleungdo) in Korea. This clade is here referred to as the oceanic hemlocks. 4CL strongly supports a sister-group relationship of the widespread northeastern Asian T. chinensis and eastern North American T. caroliniana. In contrast, chloroplast genomes, which are markedly reduced in Tsuga and relatives, strongly support Japanese T. sieboldii as sister to $T$. chinensis and moderately support T. caroliniana as sister to a clade of T. diversifolia and hemlocks from Ulleungdo. These divergent topologies suggest chloroplast capture of $T$. chinensis by Japanese T. sieboldii. Ulleungdo hemlocks are distinct from other northeastern Asian species in leaf and cone morphology and phenologically in common-garden observations. We therefore describe these hemlocks as a new species, T. ulleungensis.
\end{abstract}

Keywords-Chloroplast capture, island endemic, plastid genomes, quantitative morphology, Ulleungdo.

Pinaceae species are often weakly differentiated using DNA and morphological inferences (Campbell et al. 2005; Syring et al. 2005, 2007; Havill et al. 2008; Xiang et al. 2009). Individuals of Pinaceae typically form large populations, are long-lived, and readily cross with congeners (Tsutsui et al. 2009; Willyard et al. 2009; Zhang et al. 2010). These conditions retard evolutionary divergence by prolonging retention of ancestral polymorphisms and admixing parental genomes, resulting in morphologically similar species (Syring et al. 2005, 2007; Cun and Wang 2014). Difficulties in species delimitation in Pinaceae may also result from recent diversification (Aguirre-Planter et al. 2000, 2012; Bouillé et al. 2011), convergent evolution (Wang and Ran 2014), and hybrid speciation (Havill et al. 2008; Abbott et al. 2010; Ren et al. 2012; Xiang et al. 2015).

Delimiting Tsuga species is difficult only in eastern Asia (Table 1), where the number of recognized species is three (Eckenwalder 2009), four (Farjon 1990, 2010), or five (Fu et al. 1999). Long-accepted species, such as northern Japanese hemlock ( $T$. diversifolia) and southern Japanese hemlock (T. sieboldii), differ subtly by presence of twig pubescence, stomatal band color, and seed (ovulate) cone scale texture (Farjon 1990; Baker 2009). These species also differ in the shape and margins of the ovulate cone-scale bracts, characters that are useful across living and fossil Tsuga (LePage 2003; Xing et al. 2013).

Although widespread across northern temperate continents during the Neogene, Tsuga contracted during the Quaternary to eastern Asia, and eastern and western North America, perhaps due to its dependence on moist environments (LePage 2003; Tsuyama et al. 2014). The two western North American hemlocks, mountain hemlock (T. mertensiana) and western hemlock ( $T$. heterophylla), form a clade that is sister to the remainder of the genus (Vining 1999; Havill et al. 2008). Eastern hemlock (T. canadensis) is sister to a well-supported clade consisting of the southern Appalachian endemic Carolina hemlock (T. caroliniana) plus Asian hemlocks (Havill et al. 2008). Central Asian T. dumosa is morphologically distinct from northeastern Asian hemlocks, and T. chinensis, which is widespread in China plus a small region of Vietnam (Farjon 2010), is morphologically diverse. The Japanese endemic T. diversifolia is morphologically most similar to T. sieboldii, which is native to Japan and the small Korean island, Ulleungdo. Havill et al.'s (2008) ITS data did not resolve relationships within the clade of T. caroliniana and Asian hemlocks. Their cpDNA did find a sister-group relationship of $T$. chinensis and Japanese $T$. sieboldii and weakly supported $T$. caroliniana as sister to a clade of $T$. diversifolia and Korean $T$. sieboldii. The close relationship between northeastern Asian Tsuga and eastern North American T. caroliniana is a common pattern in the boreotropical flora (Tiffney 1985; Manos and Meireles 2015).

Ulleungdo is a volcanic island about $130 \mathrm{~km}$ east of the Korean peninsula and separated from the closest point in Japan by about $284 \mathrm{~km}$ (Fig. 1). Ulleungdo is approximately $73 \mathrm{~km}^{2}$, reaches an altitude of $983 \mathrm{~m}$ above sea level, and originated $2.7 \pm 0.9$ million years ago (Kim and Lee 1983). Ulleungdo has 30-40 endemic angiosperms (Stuessy et al. 2006; Jung et al. 2013), which make up 4-6\% of the vascular plant species on the island (Jung et al. 2013). The majority of Ulleungdo endemics are hypothesized to have evolved by anagenesis (Stuessy et al. 2006). Ulleungdo has eight gymnosperm species, all of which are native, and Ulleungdo hemlocks are the first endemic gymnosperm to be described from the island. In Korea, Tsuga is only found on Ulleungdo (Jung et al. 2013), and has been treated as T. sieboldii (Wilson 1918; Nakai 1919; Kim 1988; Lee 1993; Lee 2001; Sun 2007).

The goal of this paper is to resolve the evolutionary relationships of Ulleungdo hemlocks. We assess their phylogenetic relationships to other hemlocks with DNA 
TABLE 1. Comparison of three recent species classifications of Tsuga and Nothotsuga. NA $=$ Not Applicable.

\begin{tabular}{|c|c|c|}
\hline Eckenwalder 2009 & Farjon 2010 & Fu et al. 1999 \\
\hline $\begin{array}{l}\text { Nothotsuga longibracteata (W. C. Cheng) } \\
\text { H. H. Hu ex C. N. Page }\end{array}$ & N. longibracteata & Tsuga longibracteata W. C. Cheng \\
\hline T. canadensis Carrière & T. canadensis & NA \\
\hline T. caroliniana Engelm. & T. caroliniana & NA \\
\hline T. chinensis (Franch.) E. Pritz. in Diels & T. chinensis var. chinensis & T. chinensis var. chinensis \\
\hline T. chinensis & T. chinensis var. chinensis & $\begin{array}{l}\text { T. chinensis var. formosana (Hayata) H. L. Li \& } \\
\text { H. Keng }\end{array}$ \\
\hline T. chinensis & $\begin{array}{l}\text { T. chinensis var. oblongisquamata W. C. Cheng \& } \\
\text { L. K. Fu }\end{array}$ & $\begin{array}{l}\text { T. oblongisquamata (W. C. Cheng \& L. K. Fu) } \\
\text { L. K. Fu \& Nan Li }\end{array}$ \\
\hline T. $\times$ forrestii Downie & T. forrestii Downie & T. chinensis var. forrestii (Downie) Silba \\
\hline T. chinensis & T. chinensis var. robusta W. C. Cheng \& L. K. Fu & T. chinensis var. robusta \\
\hline T. chinensis & T. chinensis var. chinensis & T. chinensis var. patens (Downie) L. K. Fu \& Nan Li \\
\hline T. diversifolia (Maxim.) Mast. & T. diversifolia & NA \\
\hline T. dumosa Eichl. & T. dumosa & T. dumosa \\
\hline T. heterophylla Sarg. & T. heterophylla & NA \\
\hline T. $\times$ jeffreyi (A. Henry) A. Henry & T. $\times$ jeffreyi & NA \\
\hline T. mertensiana (Bong.) Carrière & T. mertensiana & NA \\
\hline T. mertensiana & T. mertensiana var. grandicona Farjon & NA \\
\hline T. sieboldii Carrière & T. sieboldii & T. sieboldii \\
\hline
\end{tabular}

sequences from nearly complete chloroplast genomes and the low-copy nuclear gene $4 C L$. We test their phenotypic distinctness with quantitative morphology and their phenological distinctness in a common garden.

\section{MAterials AND Methods}

Plant Samples-We follow Eckenwalder (2009; Table 1) in recognizing three northeastern Asian hemlocks: T. chinensis, T. diversifolia, and T. sieboldii. We collected plant tissue for DNA extraction from 14 hemlock individuals (Appendix 1), including Ulleungdo hemlock and multiple accessions of each northeastern Asian hemlock species. For quantitative morphology, we studied 78 Gray Herbarium specimens of wild-collected Asian hemlocks from across their range (Fig. 1; Table 2; Appendix 1). We studied the morphology and phenology of 18 individuals of northeastern Asian taxa growing in the Arnold Arboretum, Boston, Massachusetts, U. S. A.

DNA Extraction and Sequencing-DNA was extracted from silicapreserved leaf material with a DNeasy plant mini kit (Qiagen, Valencia, California). Leaf material was frozen in liquid nitrogen for $30 \mathrm{sec}$ before grinding. For mature leaf material the lysis buffer step was extended by several hours, up to an overnight incubation at $65^{\circ} \mathrm{C}$.

The $4 C L$ gene was amplified following primers and PCR conditions from Wang et al. (2000), using an Eppendorf Mastercycler ep (Eppendorf AG, Hamburg, Germany). We cloned PCR amplicons with a TOPO TA kit (Invitrogen, San Diego, California), and screened for the correct insert using an $E c o R 1$ digest. To assess intra-individual variation, we sequenced 10-16 colonies for each accession, including all detected variants in EcoR1 digest profiles. 4CL sequencing was performed with PCR primers at the University of Maine DNA Sequencing Facility using an ABI 3730 sequencer and an ABI Prism BigDye Terminator v3.1 cycle sequencing kit (Applied Biosystems, Foster, California). We sampled three individuals of $T$. diversifolia; two each of $T$. caroliniana, $T$. chinensis, Japanese $T$. sieboldii, and Ulleungdo hemlocks; and one T. canadensis (Appendix 1). Published sequences of $4 C L$ from $T$. canadensis (AF144525, AF144526), T. mertensiana (AF144524), and N. longibracteata (AF144523) were used as outgroups.

We generated nearly complete plastome sequences of one individual each of T. canadensis, T. caroliniana, T. chinensis, T. diversifolia, T. heterophylla, Japanese T. sieboldii, Ulleungdo hemlocks, and Nothotsuga longibracteata (Appendix 1) with Illumina second-generation sequencing technology, following techniques of Cronn et al. (2008). Sequencing was conducted on an Illumina Genome Analyzer IIx at the FAS Center for Systems Biology at Harvard University. Read length varied between 33 and 100 base pairs, and assembly coverage depth averaged $1,000 \times$, with a range of $100-2,000 \times$ (Appendix 2). We sorted raw short-read sequences by barcode using perl scripts (Knaus 2014) and assembled to a Keteleeria davidiana (NC011930) reference using the "align-reads" pipeline (Straub et al. 2011). We conducted chloroplast genome annotation using DOGMA (Wyman et al.
2004). As an outgroup, we analyzed Nothotsuga longibracteata, of southeastern Asia, the closest relative of Tsuga (Wang et al. 2000).

Phylogenetic Analyses - We manipulated DNA sequences in Geneious version 9.0.5 (http://www.geneious.com, Kearse et al. 2012). We aligned DNA sequences with MAFFT (Katoh et al. 2009), and sequence alignments were then analyzed with maximum parsimony (MP) and maximum likelihood (ML). DNA alignments are available from Dryad Digital Repository (Holman et al. 2017). Maximum parsimony analyses utilized PAUP* version $4.0 \mathrm{~b} 10$ (Swofford 2002). Parsimony heuristic searches were performed in two steps, first to find the most parsimonious tree(s) using 1,000 random addition sequence replicates with tree-bisection-reconnection (TBR). Subsequent MP bootstraps analyses utilized the same settings as above, retaining 10 trees per replicate. Selection of models for use in maximum likelihood was conducted in jModelTest version 2.1.4, using the Akaike information criterion (Guindon and Gascuel 2003; Darriba et al. 2012). Maximum likelihood analyses were conducted with Garli 2.0, with an initial run to find the best tree, followed by 1,000 bootstrap replicates (Zwickl 2006).

Consensus trees from multiple runs of Garli were constructed using Sumtrees v.3.3.1 (Sukumaran and Holder 2010). Incongruence between phylogenetic markers was analyzed by visually comparing topologies and the incongruence-length distance (ILD) test (Farris et al. 1994) implemented in PAUP* (Swofford 2002). We delimit species as phenotypic clusters (Hausdorf 2011).

Morphology-Morphological analysis of continuous and qualitative characters was conducted to assess variance within and between northeastern Asian hemlocks and test the null hypothesis of no distinguishable groups. A scoop of eight milliliters of leaves from fragment packets of herbarium specimens were numbered and randomly selected (www.random.org, Haahr 2015). We measured 11 quantitative characters for each leaf, including width at 10,50 , and $90 \%$ of leaf length, leaf length, petiole length, petiole width at point of connection with branch, width and depth of emarginate leaf apex notch, width of stomata bands, number of rows per stomatal band at midpoint of leaf, and width of resin canals (Fig. 2). Distribution of values for each character was screened using histograms and boxplots in $\mathrm{R}$ version 3.1.3 (R Core Team 2015), and extreme outliers were removed. We used analysis of variance to test the significance of all characters in discriminating between taxonomic groups. Of the 11 characters we assessed, six were significant (Table 2) and included in further analyses. Principal components analyses (PCA) and boxplots of individual characters were implemented in $R$ version 3.1.3 ( $R$ Core Team 2015). Significance of PCA axes was assessed using the brokenstick model. To conduct Tukey's post hoc test for multiple comparisons of means, we used the glht function in the multcomp package in R (Herberich et al. 2010), which is robust for comparison of means from unbalanced data. Morphological data matrix is available from Dryad Digital Repository (Holman et al. 2017).

Common Garden Leaf Morphology-We studied morphological variation in three mature individuals each of $T$. diversifolia and Japanese 


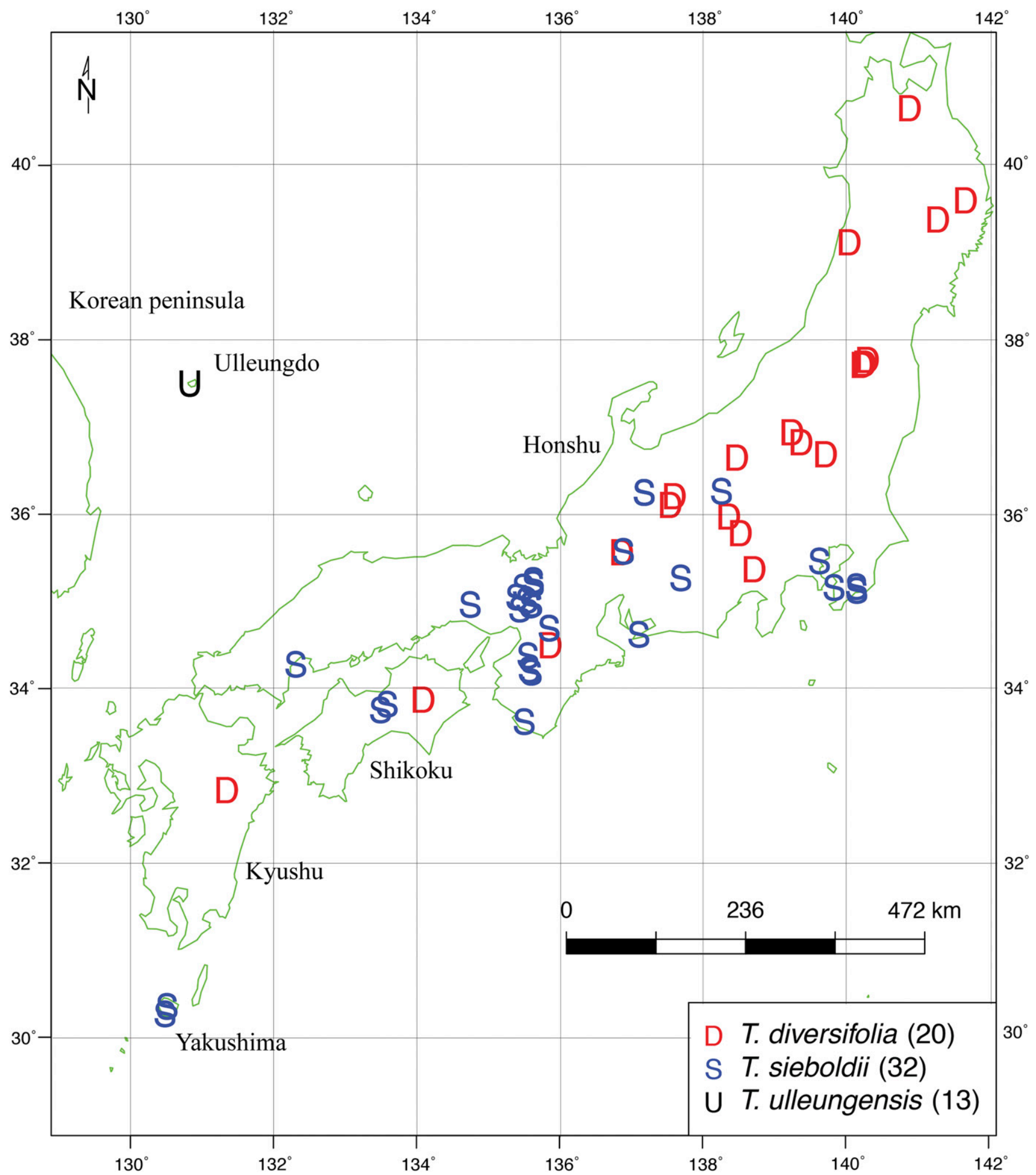

FIG. 1. Sampling of oceanic hemlock species.

T. sieboldii plus two Ulleungdo hemlocks at the Arnold Arboretum. We used four branches from each individual from the same aspect, exposure, and developmental stage.

Phenology -We recorded bud burst and leaf maturation on reproductively mature plants of Ulleungdo hemlocks, $T$. chinensis, T. diversifolia, and Japanese T. sieboldii growing out-of-doors at the Arnold Arboretum in 2010, 2011, and 2012. We measured one branch on the north, east, south, and west sides of each specimen weekly from April 1 through September 1.

\section{RESUlts}

Alignments of $4 C L$ were 1,049 base pairs in length. Preliminary phylogenetic analysis of $4 C L$ revealed two distinct copies of the gene in Tsuga, as in Larix (Semerikov and Lascoux 2003). We analyzed alleles from these two $4 C L$ copies to better understand patterns that may be attributed to retention of ancestral polymorphisms, a phenomenon of non-coalesence 
TABLE 2. Morphological differentiation of northeastern Asian Tsuga in six quantitative leaf characters, and three qualitative characters. Sample sizes are given in parentheses following taxon name. All measurements are in millimeters. Means differing significantly between T. ulleungensis and other taxa are indicated by different letters (ANOVA with post hoc Tukey HSD test). $\mathrm{a}=p<0.001 ; \mathrm{b}=p<0.01 ; \mathrm{c}=p<0.05 ; \mathrm{d}=\mathrm{not}$ significant, $p>0.05$; and $\mathrm{e}=$ irrelevant comparisons. See text for $p$ values of quantitative characters for T. sieboldii and T. ulleungensis.

\begin{tabular}{|c|c|c|c|c|}
\hline & T. chinensis (10) & T. diversifolia (20) & T. sieboldii (32) & T. ulleungensis (13) \\
\hline Leaf blade length & $9.73 \pm 2.03^{d}$ & $7.35 \pm 1.23^{\mathrm{a}}$ & $9.25 \pm 1.76^{c}$ & $10.87 \pm 1.06^{\mathrm{e}}$ \\
\hline Petiole width & $0.41 \pm 0.05^{\mathrm{d}}$ & $0.39 \pm 0.07^{\mathrm{a}}$ & $0.40 \pm 0.03^{b}$ & $0.44 \pm 0.02^{\mathrm{e}}$ \\
\hline Leaf width at apex & $1.53 \pm 0.17^{\mathrm{c}}$ & $1.56 \pm 0.11^{\mathrm{b}}$ & $1.64 \pm 0.15^{\mathrm{d}}$ & $1.74 \pm 0.10^{\mathrm{e}}$ \\
\hline Leaf notch depth & $0.07 \pm 0.02^{\mathrm{a}}$ & $0.105 \pm 0.02^{c}$ & $0.11 \pm 0.03^{\mathrm{d}}$ & $0.133 \pm 0.02^{\mathrm{e}}$ \\
\hline Leaf notch width & $0.19 \pm 0.08^{a}$ & $0.33 \pm 0.04^{b}$ & $0.33 \pm 0.06^{\mathrm{a}}$ & $0.41 \pm 0.04^{\mathrm{e}}$ \\
\hline Resin canal width & $0.11 \pm 0.03^{\mathrm{a}}$ & $0.14 \pm 0.02^{\mathrm{a}}$ & $0.13 \pm 0.02^{\mathrm{a}}$ & $0.06 \pm 0.01^{\mathrm{e}}$ \\
\hline Twig hairiness & none to sparse & moderately dense & none & none \\
\hline Cone-scale bract margins & erose & entire to crenulate & erose & crenulate \\
\hline
\end{tabular}

that is inferred in nuclear phylogenies in Pinus (Syring et al. 2007; Willyard et al. 2009) and organellar markers in Tsuga (Cun and Wang 2014). Tsuga canadensis was selected as an outgroup given its phylogenetic position as sister to Asian hemlocks plus T. caroliniana (Havill et al. 2008). The ILD tests revealed no significant differences in phylogenetic signal between the two copies, which were combined for further analysis. The combined, two-copy $4 C L$ alignment was 2,098 base pairs in length, with 46 parsimonyinformative characters, and the best-fitting model, HKY + I, was selected. The strongly supported clade of $T$. caroliniana and T. chinensis is sister to the strongly supported oceanic hemlock clade of $T$. diversifolia, $T$. sieboldii, and Ulleungdo hemlocks (Fig. 3).

The abietoid clade (Abies, Cedrus, Keteleeria, Nothotsuga, Pseudolarix, and Tsuga) has a synapomorphic reduction in the chloroplast inverted repeat (IR; Lin et al. 2010). Like Keteleeria, Nothotsuga and Tsuga chloroplast genomes are also compact, sharing intron reductions documented by $\mathrm{Wu}$ et al. (2009). Out of 68 protein-coding genes in the chloroplast, we document 13 genes $(\operatorname{acc} D, \operatorname{cem} A, \operatorname{chlN}$, matK, psbM, rpl2, rpl20, rpl22, rpoB, rpoC2, rps2, and rps4) that are shorter in Tsuga than in Keteleeria, typically by a one- or two-codon deletion near the $3^{\prime}$ end of the gene. On the other hand, insertions near the $5^{\prime}$ end of $p s a I$ and psaj make these two genes 24 total base pairs longer in Nothotsuga and Tsuga than in Keteleeria. A nine-base-pair insertion at the $5^{\prime}$ end of $p s b H$ is shared by Asian hemlocks and T. caroliniana. Numerous small (3-24 base pairs) indels are found in the giant open reading frame $y c f 2$.

The cpDNA alignment was $122,525 \mathrm{bp}$, with 1,574 parsimony informative characters. For the cpDNA dataset, the best fitting model, GTR + G, was selected, with four separate rate categories. With one exception, branches in the cpDNA phylogeny (Fig. 4) have $100 \%$ bootstrap (BS) support from MP and ML. The cpDNA phylogeny resolves $T$. caroliniana as sister to a clade of $T$. diversifolia and Ulleungdo hemlocks with moderate support (80 MPBS/77\% MLBS), and these three taxa are in turn sister to a clade of Japanese $T$. sieboldii and $T$. chinensis. The $4 C L$ and cpDNA phylogenies are therefore not congruent. Sequence divergence (Table 3) between Ulleungdo hemlocks and T. diversifolia (0.0015) is similar to that between Japanese $T$. sieboldii and T. chinensis (0.00168).

Morphology-Ulleungdo hemlocks resemble Japanese T. sieboldii in having glabrous branches, but Ulleungdo hemlocks have larger leaves (Figs. 5, 6), wider petioles, larger leaf notches, buff-colored stomatal bands, and smaller resin canals. The margins of Ulleungdo hemlocks cone-scale bracts are crenulate, with large, wave-like teeth, especially evident on the proximal-most one to three cone-scale bract margins, whereas bracts of Japanese $T$. sieboldii have finely serrate teeth (erose margins, Table 2, Fig. 7). The taxonomic utility of cone-scale bract morphology is limited by the absence of cones from many herbarium specimens. The diameter of Japanese $T$. sieboldii and T. diversifolia resin canals averages more than twice that of Ulleungdo hemlocks' (Table 2) resin canals. We did not record any overlap in resin canal diameters between Japanese T. sieboldii plus $T$. diversifolia and Ulleungdo hemlocks. Plants in a common garden setting at the Arnold Arboretum have larger leaves than those observed on wild-collected specimens. Differences between species are similar in the common garden and the wild; just as we observe in wild-collected specimens, the common garden Ulleungdo hemlocks have larger leaves on average than $T$. sieboldii, which are in turn larger than $T$. diversifolia.

Four quantitative characters (Table 2) differed significantly between Ulleungdo hemlocks and Japanese T. sieboldii (with ANOVA and post hoc Tukey HSD test): leaf length $(p=0.030)$, petiole width $(p=0.0029)$, leaf notch width $(p=0.0013)$, and resin canal width $(p=0.001)$ (Fig. $6)$. Two additional quantitative characters were included in the PCA, as they significantly differed between T. chinensis and Ulleungdo hemlocks: leaf width at apex $(p=0.027)$, and leaf notch depth $(p=0.0001)$ (Table 2$)$. The broken-stick model indicates that only two principal components were significant. PCA reveals that Ulleungdo hemlocks form a cluster that is mostly separate from a broadly overlapping grouping of $T$. diversifolia and Japanese T. sieboldii (Fig. 5). The two Japanese T. sieboldii herbarium samples (Kobayashi 1731; Wilson 6037; Appendix 1) that are close or adjacent to the Ulleungdo hemlocks cluster have large leaves and are from Yakushima, the southernmost occurrence of Japanese T. sieboldii (Fig. 1). Yakushima hemlocks, however, have large resin canals and finely-toothed ovulate cone-scale bracts typical of Japanese T. sieboldii. Two $T$. chinensis herbarium samples from Anhui Province (Steward 7194; Wilson 2100; Appendix 1) are also close or adjacent to the Ulleungdo hemlocks cluster. Like Ulleungdo hemlocks and Yakushima T. sieboldii, these two T. chinensis have large leaves with short petioles, but the diameter of their resin canals $(0.074,0.069 \mathrm{~mm}$, respectively) approach that of Ulleungdo hemlocks (Table 2). Anhui T. chinensis have, however, smaller leaf notches and rhomboid shaped ovulate 


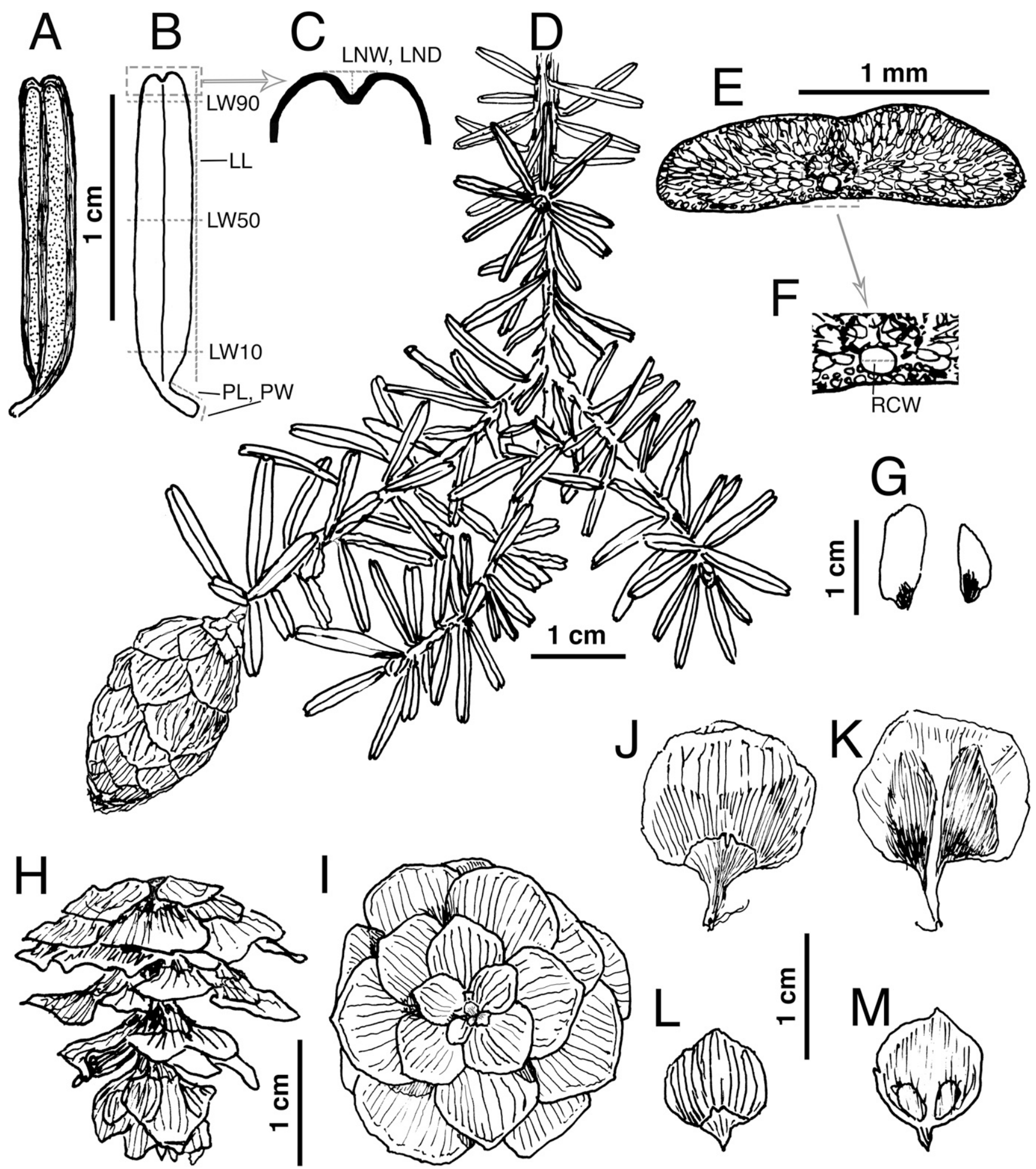

Fig. 2. Tsuga ulleungensis. A. Abaxial leaf surface. B. Adaxial leaf surface. LW90, LW50, LW10 = leaf width at 90, 50, and 10\% of leaf length, respectively. $\mathrm{LL}=$ leaf length. $\mathrm{PL}=$ petiole length. $\mathrm{PW}=$ petiole width. $\mathrm{C}$. Enlarged view of portion of leaf tip, adaxial surface. $\mathrm{LNW}=$ leaf notch width. $\mathrm{LND}=$ leaf notch depth. D. Foliated branch, with ovulate cone. E. Leaf cross section at leaf midpoint, with central resin canal near abaxial surface. F. Enlarged view of portion of leaf at midpoint, adaxial surface. RCW = resin canal width at transverse section of leaf at midpoint. G. Seeds. H. Ovulate cone, side view. I. Ovulate cone, proximal view. J. Large ovulate scale, abaxial view with bract. K. Large ovulate scale, adaxial view with impressions of winged seeds. L. Small ovulate scale, abaxial view with bract. M. Small ovulate scale, adaxial view with impression of seed body.

cone-scale bracts with irregularly serrate margins typical of T. chinensis.

Phenology-At the Arnold Arboretum, Ulleungdo hemlocks and T. chinensis break bud at nearly the same time, but
T. chinensis ceases its annual growth about four weeks later than Ulleungdo hemlocks (Fig. 8). Tsuga diversifolia has a relatively short period of growth; bud break occurs just over a week after T. chinensis and Ulleungdo hemlocks, and growth 


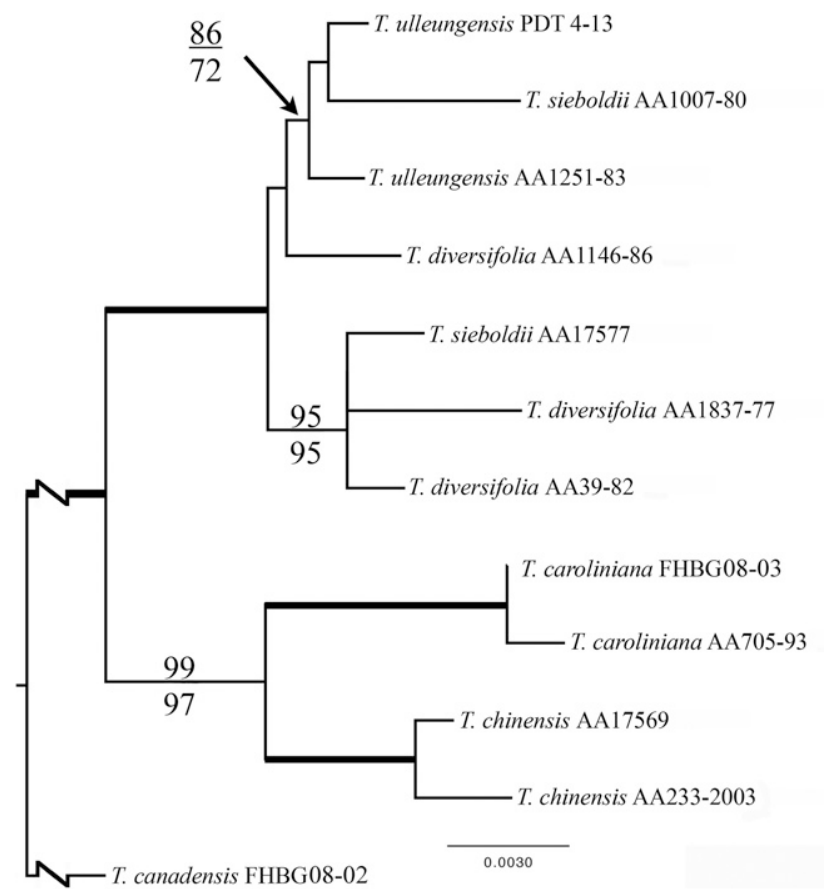

FIG. 3. Phylogram of Tsuga from two concatenated $4 C L$ paralogs, with T. canadensis as outgroup. Heavy lines indicate $100 \%$ MP and ML bootstrap support. Nodes with 70-99\% support are labeled with MPBS above and MLBS below. Nodes with less than $70 \%$ are unlabeled. Sideways Z-shaped lines indicate branch lengths that have been truncated for display. Arnold Arboretum accession numbers follow species names.

ceases about two and a half weeks earlier than Ulleungdo hemlocks. Japanese T. sieboldii initiates growth almost 40 d later (Fig. 9) than T. chinensis and Ulleungdo hemlocks, but concludes its growth a week earlier than T. chinensis. Earlier bud break in Ulleungdo hemlocks than Japanese T. sieboldii was observed in native habitats of both species during fieldwork in May 2008.

\section{Discussion}

The Species Problem in Pinaceae-Delimitation of species has been challenging in all Pinaceae genera with more than one species. This challenge is shown by Farjon's (2010) recognition of $18 \%$ more species in the family than Eckenwalder (2009). Species delimitation is difficult in Pinaceae because speciation may be slowed by long lifespans, large population sizes, extensive gene flow among populations, and large genomes (Knight et al. 2005; Syring et al. 2005, 2007). During such protracted speciation, criteria for species status (such as morphological distinctness, allelic coalescence (distinct lineage status), and reproductive isolation) may occur at different times. Complete allelic coalescence of nuclear markers, for example, could take up to 7.6 million years in Pinus (Syring et al. 2007) and has lagged behind morphological distinctness in many conifer species (Syring et al. 2005). Ulleungdo hemlocks, which have not achieved allelic monophylly in 4CL (Fig. 3) but are morphologically distinct, fit this pattern. Intergradation of taxa, such as some western North American Abies (AguirrePlanter et al. 2012) and some members of Pinus (Wang and Szmidt 1994; Jasińska et al. 2010) may represent ecogeographic but not morphological separation.

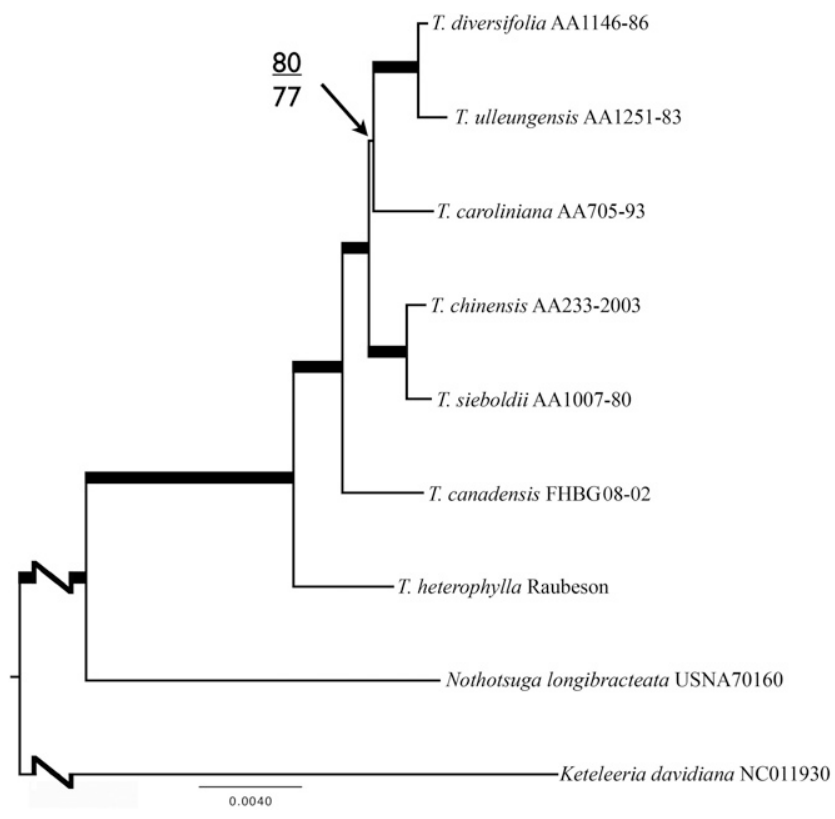

FIG. 4. cpDNA phylogram, using Nothotsuga longibracteata as outgroup. Heavy lines indicate $100 \%$ bootstrap support from maximum parsimony and likelihood. Sideways Z-shaped lines indicate branch lengths that have been truncated for display.

Although hybridization is generally not a source of difficulty in delimiting species (Rieseberg et al. 2006), it obscures some species boundaries in Pinaceae. Frequent hybridization between Picea mariana and P. rubens, for example, creates numerous intermediate forms that are difficult to distinguish from parental species (Bouillé et al. 2011). Hybridization has been reported as frequent in some genera of Pinaceae (Lanner and Van Devender 1998; Semerikov and Lascoux 2003; Kormatak et al. 2004; Bouillé et al. 2011; Xiang et al. 2015), but there is little evidence for current hybridization in Tsuga. Tsuga caroliniana and T. canadensis are partially sympatric, but hybrids have not been documented. Tsuga canadensis does not hybridize with northeastern Asian hemlocks in crosspollination trials, but $T$. caroliniana will produce fertile hybrids with northeastern Asian hemlocks (Bentz et al. 2002). Morphological intermediates between $T$. heterophylla and T. mertensiana have been attributed to hybridization. Phytochemical analysis showed that hybridization between the two species is rare, however, and morphological intermediacy was attributed to phenotypic plasticity (Taylor 1972). Support for a sister-group relationship of T. heterophylla and T. mertensiana is unequivocal from ITS, but only moderately supported by cpDNA, which may be evidence of past hybridization (Havill et al. 2008). Tsuga chinensis var. forrestii is morphologically intermediate between T. dumosa and T. chinensis and has been hypothesized to be their hybrid (Eckenwalder 2009). In contrast, ITS, cpDNA, and mtDNA place T. chinensis var. forrestii close to T. chinensis and far from T. dumosa (Havill et al. 2008, Cun and Wang 2014). A close relationship between $T$. chinensis var. chinensis and T. chinensis var. forrestii was hypothesized to result from their progenitor-derivative relationship and subsequent introgression from $T$. chinensis var. forrestii to T. chinensis var. chinensis (Cun and Wang 2014).

Ancient hybridization has been suggested in many conifers (Wei and Wang 2004). ITS phylogenies divide Larix into Eurasian and North American clades (Semerikov and Lascoux 
TABLE 3. Kimura 2-parameter cpDNA sequence divergence.

\begin{tabular}{|c|c|c|c|c|c|c|c|c|}
\hline & K. davidiana & N. longibracteata & T. heterophylla & T. canadensis & T. chinensis & T. sieboldii & T. ulleungensis & T. diversifolia \\
\hline \multicolumn{9}{|l|}{ Keteleeria davidiana } \\
\hline Nothotsuga longibracteata & 0.04502 & & & & & & & \\
\hline Tsuga heterophylla & 0.04288 & 0.02284 & & & & & & \\
\hline T. canadensis & 0.04328 & 0.02327 & 0.00837 & & & & & \\
\hline T. chinensis & 0.04395 & 0.02346 & 0.00807 & 0.00594 & & & & \\
\hline T. sieboldii & 0.04343 & 0.02374 & 0.00818 & 0.00615 & 0.00168 & & & \\
\hline T. ulleungensis & 0.04462 & 0.02448 & 0.00884 & 0.00653 & 0.00476 & 0.00501 & & \\
\hline T. diversifolia & 0.04371 & 0.02314 & 0.00791 & 0.00613 & 0.00418 & 0.00416 & 0.0015 & \\
\hline T. caroliniana & 0.04369 & 0.02359 & 0.00833 & 0.00601 & 0.00435 & 0.00457 & 0.00507 & 0.00426 \\
\hline
\end{tabular}

2003). Chloroplast phylogenies, on the other hand, resolved Eurasian L. sibirica as sister to all other Larix. Semerikov and Lascoux (2003) suggested that this incongruence arose through ancient hybridization between a member of the
Eurasian clade Larix and an extinct, stem-lineage Larix. Taiwanese endemic Pseudotsuga wilsoniana retains divergent copies of LEAFY that may be a signal of introgression of ancestors of $P$. brevifolia and the $P$. gaussenii- $P$. sinensis- $P$. japonica

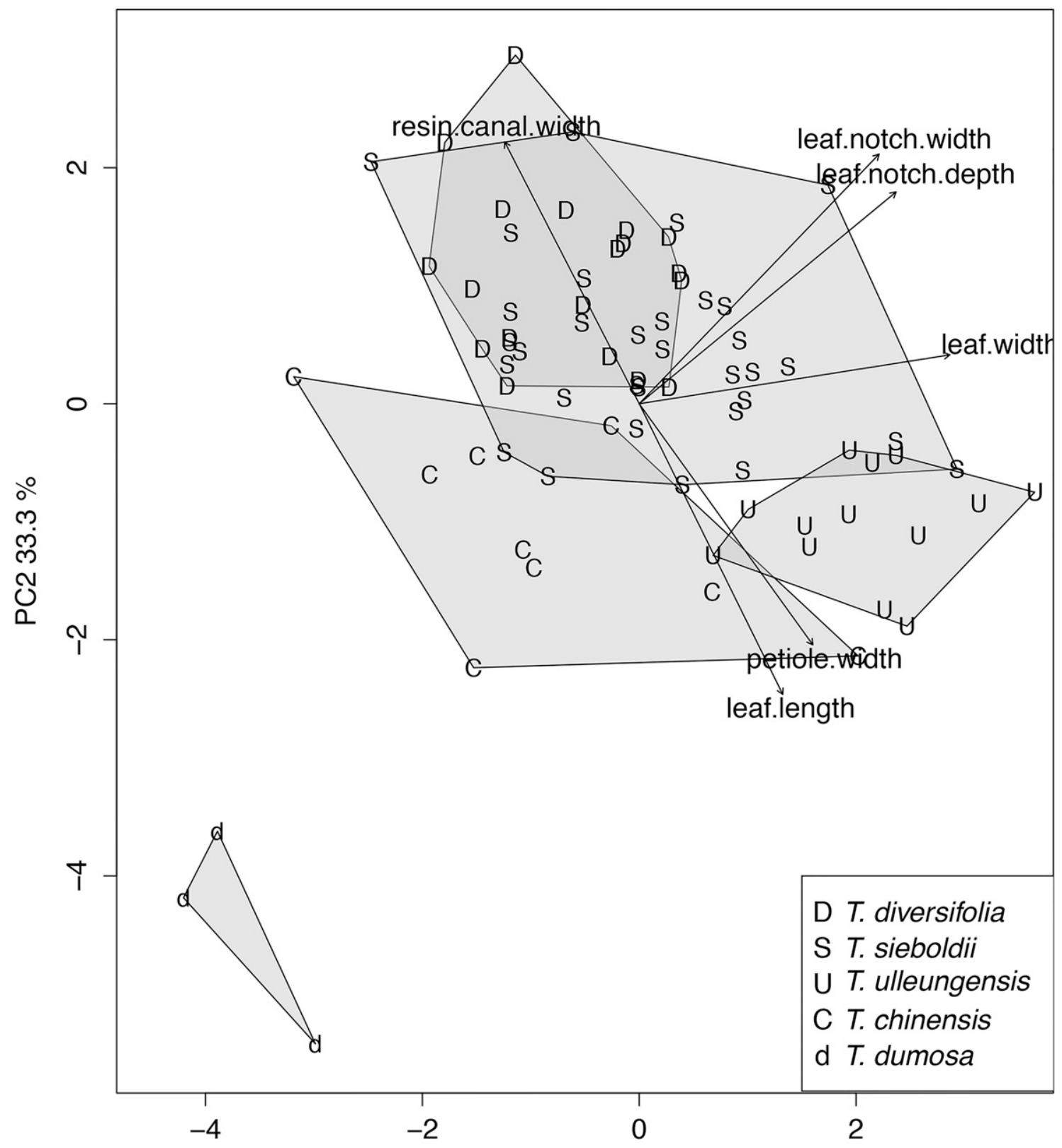

PC1 $42.9 \%$

FIG. 5. PCA biplots of morphological analyses for 78 accessions of Asian Tsuga. The percentage of variation represented in each PCA axis is displayed. Vectors depict contributions of quantitative characters. See text for a fuller description of leaf morphological characters. 
Leaf Length, excluding petiole

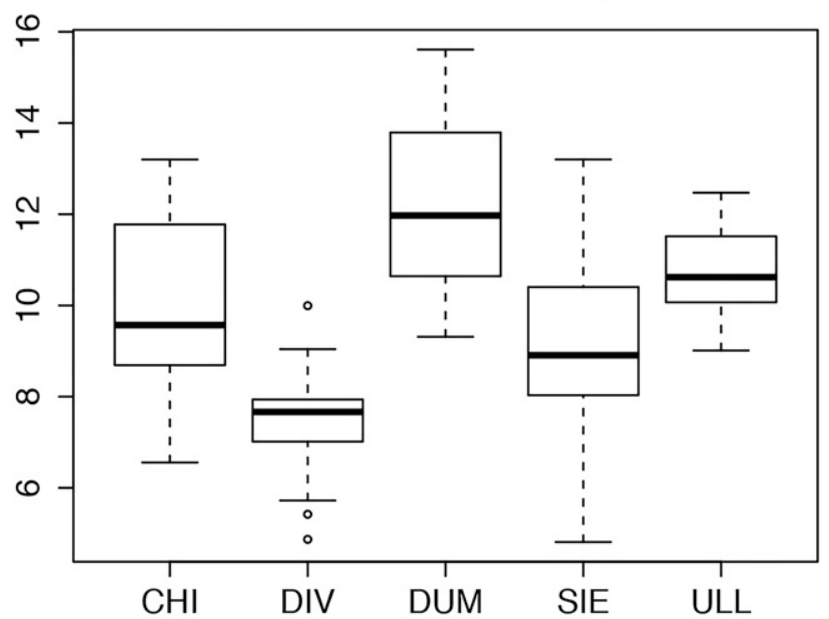

Petiole Width

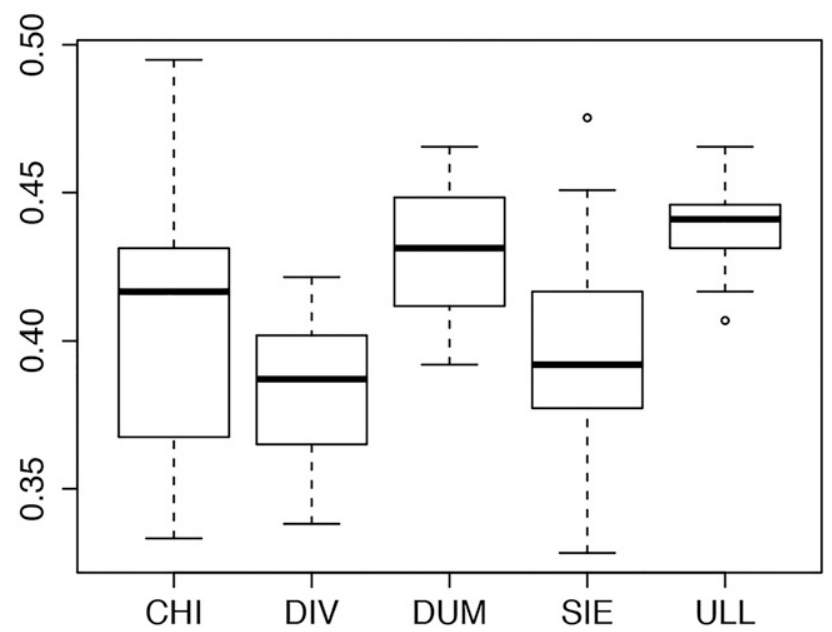

Leaf Notch Depth

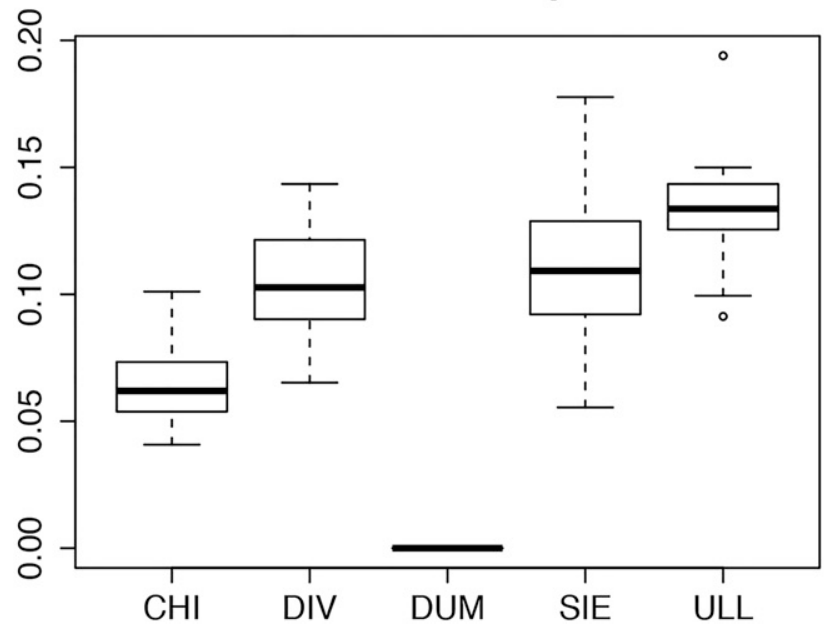

Leaf Width at $90 \%$ of leaf length

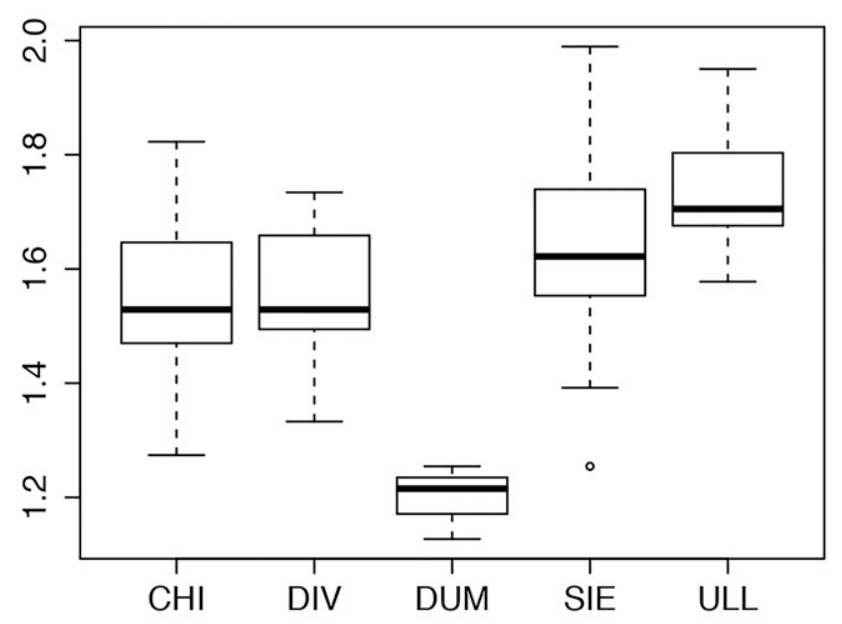

Resin Canal Width

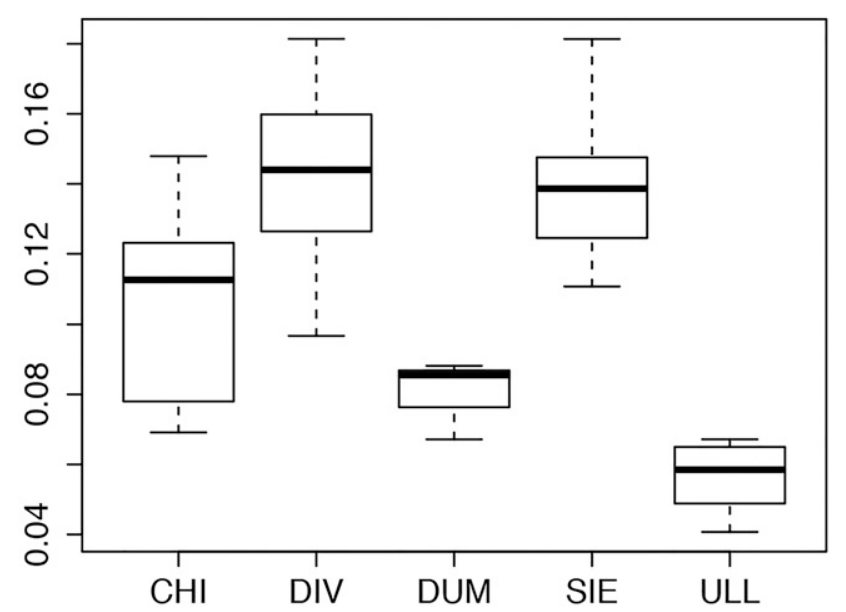

Leaf Notch Width

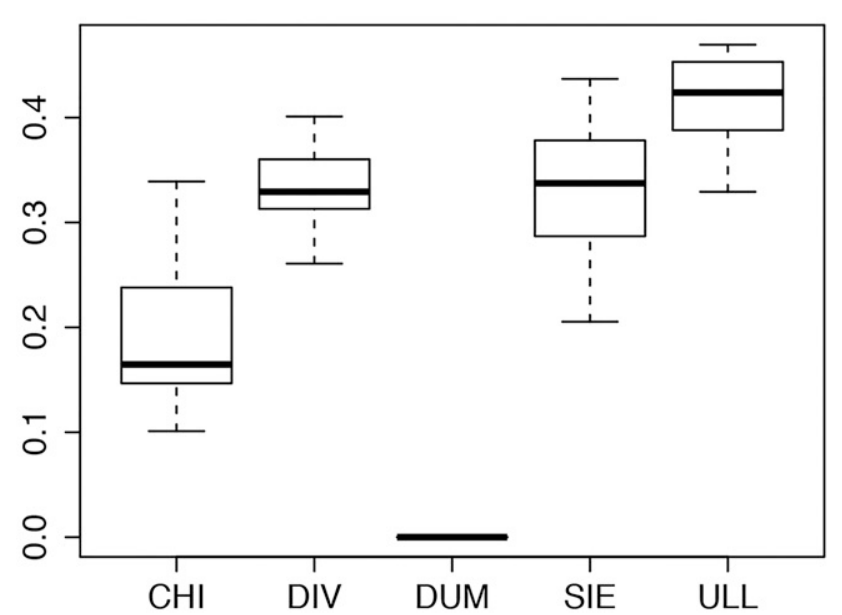

FIG. 6. Boxplots of Asian Tsuga leaf morphology. Y-axis is millimeters. $\mathrm{CHI}=$ T. chinensis $(10$ accessions); DIV = T. diversifolia (20 accessions); DUM = T. dumosa (3 accessions); SIE $=$ T. sieboldii (32 accessions); ULL $=$ T. ulleungensis (13 accessions). 


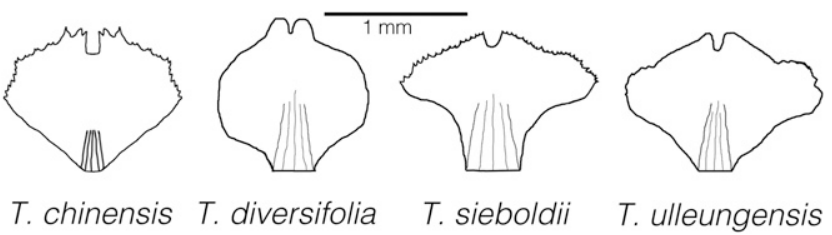

FIG. 7. Bract margins and shapes of northeastern Asian Tsuga, drawn from proximal (closest to the peduncle) 2-3-ovulate cone scales.

clade (Wei et al. 2010). Eastern Asian Thuja koraiensis apparently acquired an eastern North American T. occidentalis chloroplast (Peng and Wang 2008).

In Abies, Asian-North American disjunct section Balsamea is monophyletic in ITS, but paraphyletic in cPDNA, with the North American Balsamea species sister to a clade of sections Momi, Pseudopicea, and Asian Balsamea species (Xiang et al. 2015). Xiang et al. (2015) posited that section Balsamea originated by ancient hybridization with northeastern Asian firs contributing pollen (cpDNA) and North American firs as the seed parent (mitochondrial DNA), followed by backcrossing between Asian Balsamea and sections Momi and Pseudopicea (or their ancestors). CpDNA placed Tsuga dumosa in a clade containing T. chinensis and T. sieboldii, whereas ITS supported $T$. dumosa as sister to a clade of $T$. caroliniana and all other Asian hemlocks (Havill et al. 2008). Tsuga dumosa may be a hybrid between an extinct Eurasian hemlock that was similar to T. canadensis and an Asian hemlock (Havill et al. 2008). Finally, conflict between $4 C L$, which has T. caroliniana and T. chinensis as sister species (Fig. 3), and cpDNA, which has T. caroliniana as sister to the clade of $T$. diversifolia and Ulleungdo hemlocks may be evidence for an ancient hybridization involving T. caroliniana.

Evolution of Ulleungdo Hemlocks-The 4CL phylogeny defines two clades of northeastern Asian hemlocks: the T. caroliniana-T. chinensis clade and the oceanic clade (Fig. 3). The T. caroliniana-T. chinensis clade has smaller leaf notches and shorter petioles than oceanic hemlocks (Nan and Li-kuo 1997), and morphology shows strong similarities among hemlocks of the oceanic clade (Figs. 5, 6). Because Ulleungdo hemlocks are genetically most closely related to, but morphologically and phenologically distinct from the Japanese hemlocks, we describe them as the new species, T. ulleungensis.

Of the 30-40 endemic vascular plants on Ulleungdo, most are assumed to result from progenitor-derivative relationships because they are the only species in their genera on the island

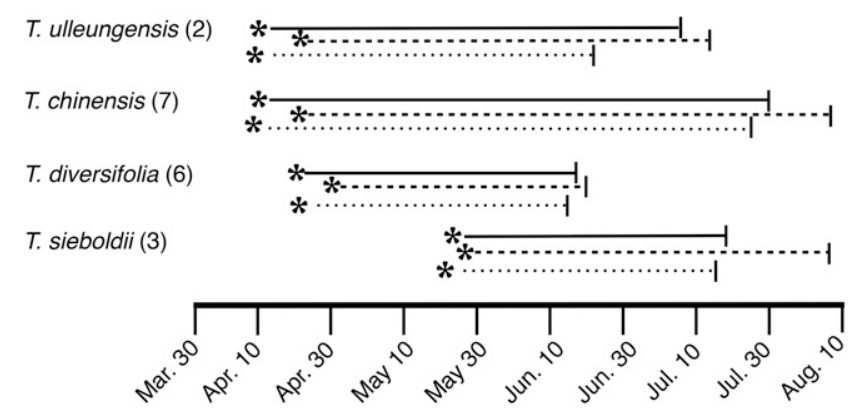

FIG. 8. Phenology of Asian Tsuga at the Arnold Arboretum from bud break (asterisk) to growth cessation (vertical line). Numbers of accessions are in parentheses following species. Solid lines indicate 2010, dashed lines 2011, and dotted lines 2012.
(Stuessy et al. 2006). Lack of resolution within the $4 C L$ oceanic clade blocks identification of a progenitor of T. ulleungensis. Our two $4 C L$ loci together moderately support a sister-group relationship of our two accessions of T. ulleungensis and one of our two accessions of T. sieboldii (Fig. 3). However, our other accession of $T$. sieboldii nests with $T$. diversifolia in a wellsupported clade (Fig. 3). While T. diversifolia and T. sieboldii are the most morphologically similar Asian hemlock species, T. ulleungensis is morphologically closest to T. sieboldii and relatively distinct from $T$. diversifolia (Figs. 5, 6). It is therefore plausible that $T$. ulleungensis evolved anagenetically from $T$. sieboldii prior to the latter's putative capture of the T. chinensis chloroplast.

Hybridization may have been involved in the ancestry of the Ulleungdo endemic Fagus multinervis based on incongruence between cpDNA and LEAFY (Oh et al. 2016). In addition, it appears to be distinct from but closely related to the Japanese endemic F. japonica and the Chinese F. engleriana. The prevalence of hybridization in conifers suggests its potential role in the ancestry of T. ulleungensis, but there is no clear evidence for this possibility.

Use of cpDNA as a molecular clock would be misleading for $T$. sieboldii because of putative chloroplast capture. If T. sieboldii and T. ulleungensis are indeed sister taxa, then their divergence would have been more recent than Havill et al.'s (2008) estimate of about 10 MYA for the split between T. ulleungensis and T. diversifolia. Volcanic analyses indicate that Ulleungdo originated about 2.7 MYA (Kim and Lee 1983) and has likely been occupied by vegetation only since 1.7 MYA (Kim 1985). While the oceanic clade does not currently occur on mainland Asia, fossils similar to T. diversifolia were widely distributed in North America and Eurasia in the Eocene (Matsumoto et al. 1995; LePage 2003). Miocene fossils from Japan resemble $T$. caroliniana, T. diversifolia, and T. heterophylla (LePage 2003), and Tsuga fossils from the Pliocene have been discovered on the Korean mainland (Kong 2000). Despite the presence of suitable habitat, $T$. diversifolia is currently absent from Hokkaido, but was present there in the late Quaternary (Tsuyama et al. 2014). Tsuyama et al. (2014) hypothesized that T. diversifolia was extirpated from Hokkaido by the colder, drier climate during the last glacial period, and has not yet been able to recolonize. A similar climate in Korea in the late Quaternary may have restricted Korean Tsuga to the climatically milder Ulleungdo. This glacial refuge may have been the place of origin of T. ulleungensis.

\section{TAXONOMIC TREATMENT}

Tsuga ulleungensis G. P. Holman, Del Tredici, Havill, N. S. Lee, and C. S. Campb., sp. nov.-TYPE: SOUTH KOREA. Ulleungdo. 2 June 1917, E. H. Wilson 8529 (GH!).

Korean name: Ul-leung-sol-song-na-mu

Trees to $22 \mathrm{~m}$, trunk $0.5-0.8 \mathrm{~m}$ diam. Branchlets glabrous, $1-1.5 \mathrm{~mm}$ in diam. Buds: 2-3(-4.1) $\mathrm{mm}$ long, 1.8-2.4(-3.8) $\mathrm{mm}$ wide; globular or obovoid; glabrous; scales orbicular, dark brown, with crenate margins. Mature leaves: petioles 0.9-1.6 mm long, 0.3-0.6 mm wide; blades (4-)8-14(-22) $\mathrm{mm}$ long, (1.0-)1.7-2.1(-2.3) mm wide; base attenuate; margins entire and slightly thickened; apex emarginate; hypostomatic, stomata in two broad, dull white to buff bands on either side of midrib, each band with mostly 8 rows of stomata, decreasing to 2-3 proximally, and 4-5 distally; with a single resin canal, 

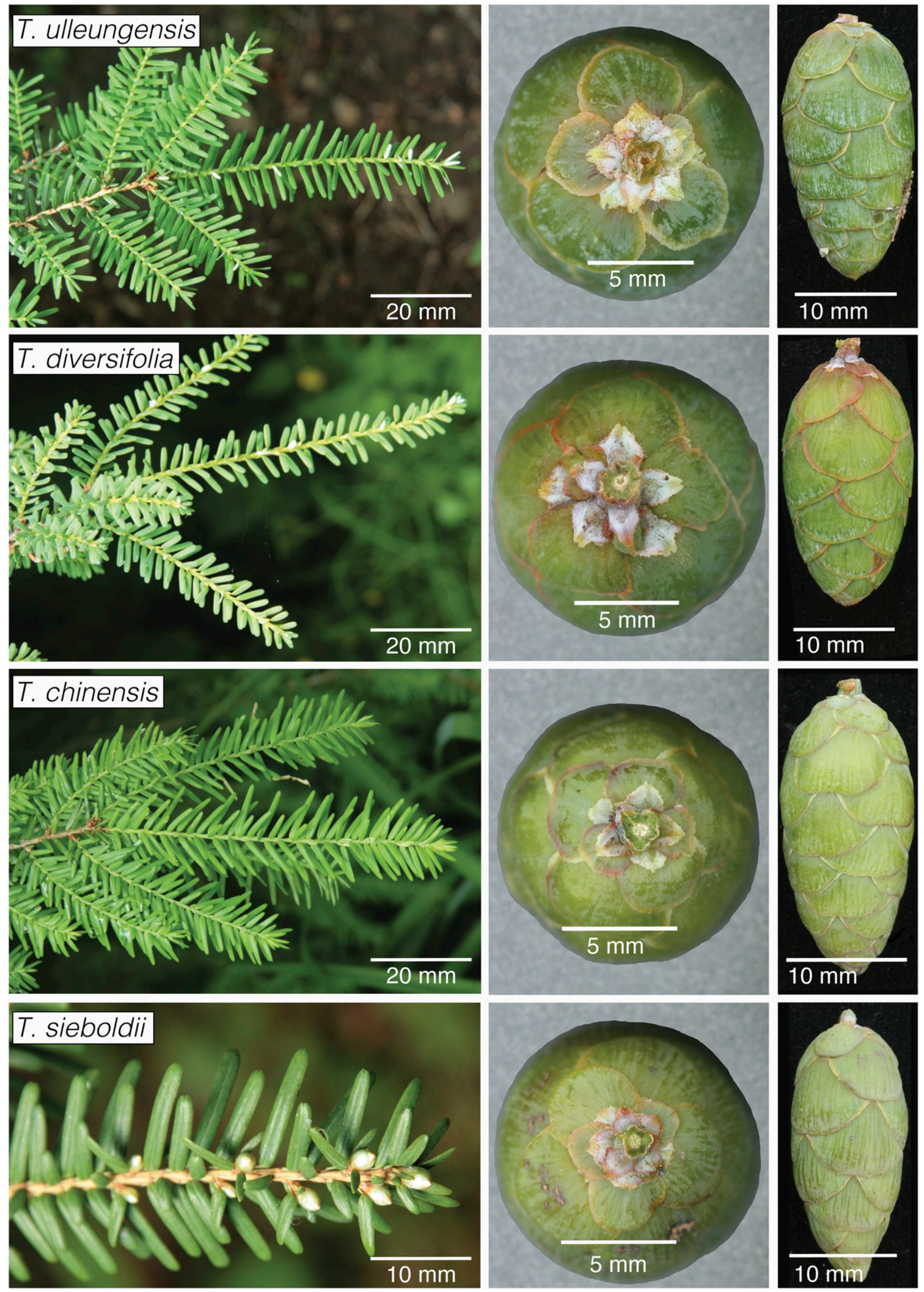

FIG. 9. Comparison of northeastern Asian Tsuga. From left to right: foliated branches on 23 May 2012, showing phenological state; proximal view of ovulate cone, showing ovulate cone-scale bracts near the peduncle; side view of ovulate cone. 


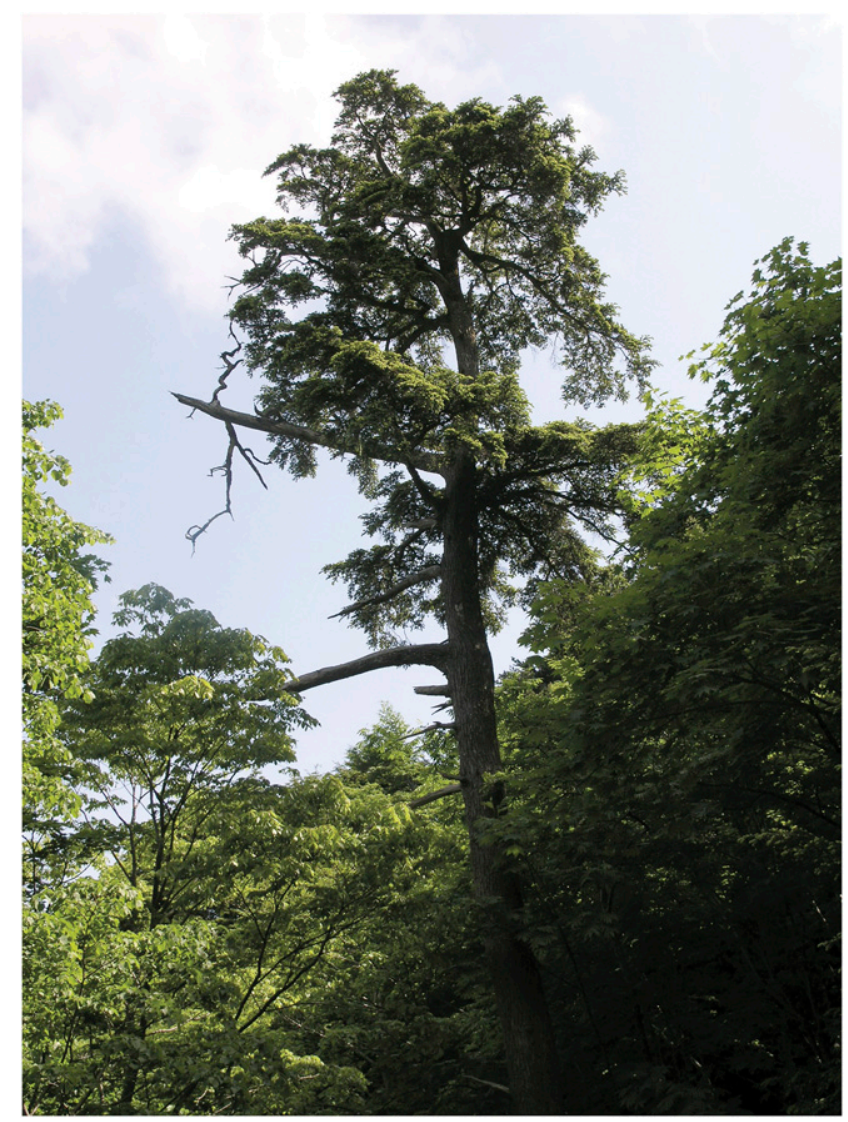

FIG. 10. Mature tree of T. ulleungensis, approximately $30 \mathrm{~m}$ tall, $450 \mathrm{~m}$ elevation, 11 May 2008, at Namseo, Taeha Ryeong Protected Reserve (Natural Monument \#50) on Ulleungdo. Photo credit: Peter Del Tredici.

0.4-0.7 $\mathrm{mm}$ in diam at midpoint of leaf. Pollen cones $4-8 \mathrm{~mm}$ long, reddish-purple. Young ovulate cones purple; bracts broader than long, with more or less crenulate margins, apex with a bifid apical projection 0.5 times as long as bract body. Mature ovulate cones globular to ovoid; $19-30 \mathrm{~mm}$ long,
18-26 mm wide when open; on 1-2 mm long peduncles; cone scales number 20-26, 9-15 mm long, 10-15 mm wide. Seeds 4-5.5 mm long, 2-2.5 mm wide; with wings $4.5-8.5 \mathrm{~mm}$ long, 3.4-4.2 mm wide. Figure 2.

Additional Specimens Examined-All specimens are from Korea, North Gyeongsang Province. Specimen information is organized by locality, date, collector, collection number (herbarium). Specimens from botanical gardens also include the garden, accession number, and wild collection locality, if known. Plants included in the common garden phenology study are noted as CG \#. GenBank accession numbers for specimens used in molecular analyses indicated as: (cpDNA; 4CL locus $1 ; 4 C L$ locus 2). A dash (-) indicates locus not sequenced for that specimen. $\mathrm{AA}=$ Arnold Arboretum; cult. $=$ in cultivation; PDT $=$ collected by Peter Del Tredici. AA 1251-83A, cult., CG \#4, wild origin: Namseo, between Taeha-dong and Manyang-dong, voucher: Holman 09-16 (AAH) (KX256185; KX354396; KX354397); AA 1251-83B, cult., CG \#3, wild origin: Namseo, between Taeha-dong and Manyang-dong, voucher: Holman 08-13 (AAH); Jeodong, Jeodong, 35 m, 10 May 2008, PDT 3; Jeodong, Sol-song-na-mu, 22 Feb 2005, Lee, Y.N. (AAH); Namseo, Taeha Ryeong Protected Reserve, 440-480 m, 11 May 2008, PDT 4-1, 8, 13 (-; KX354394; KX354395), 15, 20, and 24 (AAH); Namseo, below the Taeha Ryeong Protected Reserve, 310 m, 11 May 2008, PDT 5-2 (AAH); Namseo, end of paved road \#5, below the Taeha Ryeong Protected Reserve, 240 m, 11 May 2008, PDT 7-2 and 3 (AAH); Nari, Nari Basin, 400 m, 11 May 2008, PDT 8; Ulleung, Naesujeon, 10 May 2008, PDT 1 (AAH).

Distribution and Habitat-Tsuga ulleungensis is known only from Ulleungdo, where it grows on north facing slopes from 310 to $500 \mathrm{~m}$ above sea level (Fig. 10). Plants occur primarily on well-drained rocky ridges in a forest community type dominated by Pinus parviflora Siebold \& Zuccarini (Kim 1988). Other woody plants commonly associated with T. ulleungensis include Acer pseudosieboldianum subsp. takesimense (Nakai) P.C. de Jong, Camellia japonica L., and Fagus multinervis Nakai.

Conservation-According to IUCN criteria, T. ulleungensis may be considered "critically endangered" due to its restricted geographic range (IUCN 2001). Pacific islands are a global hotspot for endemic conifers (Rumeu et al. 2014), and recognition of $T$. ulleungensis evidences uniqueness of the Ulleungdo flora.

Etymology-The epithet "ulleungensis" is derived from Ulleungdo, where the new species is found.

\section{Key to Oceanic Hemlocks}

1. Twigs hairy, stomatal bands snow-white, proximal (closest to the peduncle) $2-3$ ovulate cone-scale bract margins entire to

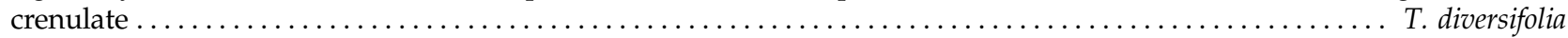

1. Twigs glabrous, stomatal bands dull white to buff, proximal $2-3$ ovulate cone-scale bract margins erose to crenulate ... 2

2. Resin canals at midpoint of leaf length $0.8-1.5 \mathrm{~mm}$ in diam, proximal $2-3$ ovulate cone-scale bract margins erose to denticulate (with many tiny sharply-pointed teeth distributed along the whole margin) .......... T. sieboldii

2. Resin canals at midpoint of leaf length $0.40-0.7 \mathrm{~mm}$ in diam, proximal 2-3 ovulate cone-scale bract margins crenulate to entire (with small, rounded teeth on the sides and no teeth or wavy, large teeth towards central cone-scale bract notch)

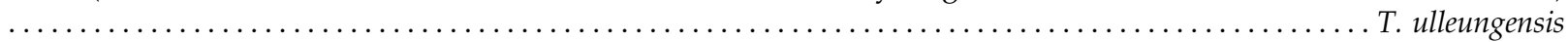

AcKnowLedgments. We thank Susan Bentz of the United States National Arboretum, and Kathryn Richardson and Kyle Port of the Arnold Arboretum for facilitating access to living plant materials; Eric Doucette and Joyce Longcore for helpful comments on the manuscript; and Alison Dibble for illustrating the new species. This paper is part of the Ph.D. thesis research of Garth Holman and was supported by NSF Gymnosperm Tree of Life grant (0629817) and in the USDA National Institute of Food and Agriculture, Hatch project number ME0-21405 to C. S. Campbell.

\section{Literature Cited}

Abbott, R. J., M. Hegarty, and S. Hiscock. 2010. Homoploid hybrid speciation in action. Taxon 59: 1375-1386.
Aguirre-Planter, E., G. Furnier, and L. Eguiarte. 2000. Low levels of genetic variation within and high levels of genetic differentiation among populations of species of Abies from southern Mexico and Guatemala. American Journal of Botany 87: 362-371.

Aguirre-Planter, A. R., J. P. Jaramillo-Correa, S. Gómez-Acevedo, D. P. Khasa, J. Bousquet, and L. E. Eguiarte. 2012. Phylogeny, diversification rates and species boundaries of Mesoamerican firs (Abies, Pinaceae) in a genus-wide context. Molecular Phylogenetics and Evolution 62: 263-274.

Baker, J. D. 2009. A phylogenetic analysis of species relationships in hemlocks, the genus Tsuga (Pinaceae). Electronic Theses and Dissertations. http://dc.etsu.edu/etd/1791.

Bentz, S., L. Riedel, M. Pooler, and A. Townsend. 2002. Hybridization and self-compatibility in controlled pollinations of eastern North American and Asian hemlock (Tsuga) species. Journal of Arboriculture 28: 200-204. 
Bouillé, M., S. Senneville, and J. Bousquet. 2011. Discordant mtDNA and cpDNA phylogenies indicate geographic speciation and reticulation as driving factors for the diversification of the genus Picea. Tree Genetics $\mathcal{E}$ Genomes 7: 469-484.

Campbell, C. S., W. Wright, M. Cox, T. Vining, C. Major, and M. Arsenault. 2005. Nuclear ribosomal DNA internal transcribed spacer 1 (ITS1) in Picea (Pinaceae): Sequence divergence and structure. Molecular Phylogenetics and Evolution 35: 165-185.

Cronn, R., A. Liston, M. Parks, D. Gernandt, R. Shen, and T. Mockler. 2008. Multiplex sequencing of plant chloroplast genomes using Solexa sequencing-by-synthesis technology. Nucleic Acids Research 36: e122.

Cun, Y.-Z. and X.-Q. Wang. 2014. Phylogeography and evolution of three closely related species of Tsuga (hemlock) from subtropical eastern Asia: Further insights into speciation of conifers. Journal of Biogeography 42: 315-327.

Darriba, D., G. L. Taboada, R. Doallo, and D. Posada. 2012. jModelTest 2: More models, new heuristics and parallel computing. Nature Methods 9: 772 .

Eckenwalder, J. E. 2009. Tsuga. Pp. 619-626 in Conifers of the world: The complete reference. Portland, Oregon: Timber Press.

Farjon, A. 1990. Tsuga. Pp. 147-169 in Pinaceae: Drawings and description of the genera: Abies, Cedrus, Pseudolarix, Keteleeria, Nothotsuga, Tsuga, Cathaya, Pseudotsuga, Larix and Picea. Konigstein: Koeltz Scientific Books.

Farjon, A. 2010. A handbook of the world's conifers. Leiden/Boston: E. J. Brill.

Farris, J. S., M. Källersjö, A. G. Kluge, and C. Bult. 1994. Testing significance of congruence. Cladistics 10: 315-319.

Fu, L., N. Li, and R. R. Mill. 1999. Pinaceae. Pp. 11-52 in Flora of China vol. 4, eds. W. Zhengyi, P. H. Raven, and H. Deyuan. St. Louis and Beijing: Missouri Botanical Garden Press and Science Press.

Guindon, S. and O. Gascuel. 2003. A simple, fast, and accurate algorithm to estimate large phylogenies by maximum likelihood. Systematic Biology 52: 696-704.

Haahr, M. 2015. True random number service. http:/ / www.random.org/.

Hausdorf, B. 2011. Progress toward a general species concept. Evolution 65 923-931.

Havill, N., C. S. Campbell, T. Vining, B. LePage, R. Bayer, and M. Donoghue. 2008. Phylogeny and biogeography of Tsuga (Pinaceae) inferred from nuclear ribosomal ITS and chloroplast DNA sequence data. Systematic Botany 33: 478-489.

Herberich, E., J. Sikorski, and T. Hothorn. 2010. A robust procedure for comparing multiple means under heteroscedasticity in unbalanced designs. PLoS One 5: e9788.

Holman, G., P. Del Tredici, N. Havill, N. S. Lee, R. Cronn, S. Mathews, L. Raubeson, and C. S. Campbell. 2017. Data from: A new species and introgression in Eastern Asian Hemlocks (Pinaceae: Tsuga). Dryad Digital Repository. http://dx.doi.org/10.5061/dryad.2r12j.

IUCN. 2001. IUCN red list categories and criteria. Version 3.1. Gland, Switzerland and Cambridge, U. K.: IUCN Species Survival Commission. IUCN.

Jasińska, A. K. W. Wachowiak, E. Muchewicz, K. Boratyńska, J. M. Montserrat, and A. Boratyński. 2010. Cryptic hybrids between Pinus uncinata and P. sylvestris. Botanical Journal of the Linnean Society 163: $473-485$..

Jung, S.-Y., S.-H. Park, C.-H. Nam, H.-J. Lee, Y.-M. Lee, and K.-S. Chang. 2013. The distribution of vascular plants in Ulleungdo and nearby island regions (Gwaneumdo, Jukdo), Korea. Journal of Asia-Pacific Biodiversity 6: 123-156.

Katoh, K., G. Asimenos, and H. Toh. 2009. Multiple alignment of DNA sequences with MAFFT. Pp. 39-64 in Bioinformatics for DNA Sequence Analysis, ed. D. Posada. Methods in Molecular Biology 537. New York: Humana Press.

Kearse, M., R. Moir, A. Wilson, S. Stones-Havas, M. Cheung, S. Sturrock, S. Buxton, A. Cooper, S. Markowitz, C. Duran, T. Thierer, B. Ashton, P. Mentjies, and A. Drummond. 2012. Geneious Basic: An integrated and extendable desktop software platform for the organization and analysis of sequence data. Bioinformatics 28: 1647-1649.

Kim, Y. K. 1985. Petrology of Ulreung volcanic island, Korea. Journal of the Japanese Association of Mineralogists. Petrologists and Economic Geologists 80: 128-135.

Kim, J.-W. 1988. The phytosociology of forest vegetation on Ulreung-do, Korea. Phytocoenologia 16: 259-281.

Kim, Y. K. and D. S. Lee. 1983. Petrology of alkali volcanic rocks in northern part of Ulreung Island. Journal of the Korean Institute of Mining Geology 16: 19-36. (in Korean with English abstract).

Knaus, B. 2014. Short-read toolbox. http://brianknaus.com. (last accessed 20 April 2014).
Knight, C., N. A. Molinari, and D. A. Petrov. 2005. The large genome constraint hypothesis: Evolution, ecology and phenotype. Annals of Botany 95: 177-190.

Kong, W. S. 2000. Vegetational history of the Korean peninsula. Global Ecology and Biogeography 9: 391-402.

Kormatak, A., B. Vookova, B. Ziegenhagen, H. Kwon, and Y. Hong. 2004. Chloroplast DNA variation in some representatives of the Asian, North American and Mediterranean firs (Abies spp). Silvae Genetica 53: 99-104.

Lanner, R. M. and T. R. Van Devender. 1998. The recent history of pinyon pines in the American Southwest. Pp. 171-182 in Ecology and Biogeography of Pinus, ed. D. M. Richardson. Cambridge: Cambridge University Press.

Lee, T. B. 1993. Illustrated Flora of Korea. Seoul: Hyangmunsa.

Lee, Y. N. 2001. Flora of Korea. Seoul: Kyohak.

LePage, B. 2003. A new species of Tsuga (Pinaceae) from the middle Eocene of Axel Heiberg Island, Canada, and an assessment of the evolution and biogeographical history of the genus. Botanical Journal of the Linnean Society 141: 257-296.

Lin, C. P., J. P. Huang, C. S. Wu, C. Y. Hsu, and S. M. Chaw. 2010. Comparative chloroplast genomics reveals the evolution of Pinaceae genera and subfamilies. Genome Biology and Evolution 2: 504-517.

Manos, P. S. and J. E. Meireles. 2015. Biogeographic analysis of the woody plants of the Southern Appalachians: Implications for the origins of a regional flora. American Journal of Botany 102: 780-804.

Matsumoto, M., T. Ohsawa, and M. Nishida. 1995. Tsuga shimokawaensis, a new species of permineralized conifer leaves from the Middle Miocene Shimokawa Group, Hokkaido, Japan. Journal of Plant Research 108: 417-428.

Nakai, T. 1919. Report on the vegetation of the island Ooryongto or Dagelet Island, Corea. Seoul: The Government of Chosen.

Nan, L. and F. Li-kuo. 1997. Notes on gymnosperms I. Taxonomic treatments of some Chinese conifers. Novon: A Journal for Botanical Nomenclature 7: 261-264.

Oh, S. H., J. W. Youm, Y. L. Kim, and D. Y. Kim. 2016. Phylogeny and Evolution of Endemic Species on Ulleungdo Island, Korea: The Case of Fagus multinervis (Fagaceae). Systematic Botany 41: 617-625.

Peng, D. and X. Wang. 2008. Reticulate evolution in Thuja inferred from multiple gene sequences: Implications for the study of biogeographical disjunction between eastern Asia and North America. Molecular Phylogenetics and Evolution 47: 1190-1202.

R Core Team. 2015. R: A language and environment for statistical computing. $\mathrm{R}$ Foundation for Statistical Computing, Vienna, Austria. http:/ /www. R-project.org/.

Ren, G. P., R. J. Abbott, Y. F. Zhou, L. R. Zhang, Y. L. Peng, and J. Q. Liu. 2012. Genetic divergence, range expansion and possible homoploid hybrid speciation among pine species in Northeast China. Heredity 108: 552-562.

Rieseberg, L., T. Wood, and E. Baack. 2006. The nature of plant species. Nature 440: 524-527.

Rumeu, B., V. Afonso, J. M. Fernández-Palacios, and M. Nogales. 2014. Diversity, distribution and conservation status of island conifers: a global review. Diversity \& Distributions 20: 272-283.

Semerikov, V. L. and M. Lascoux. 2003. Nuclear and cytoplasmic variation within and between Eurasian Larix (Pinaceae) species. American Journal of Botany 90: 1113-1123.

Stuessy, T. F., G. Jakubowsky, R. S. Gomez, M. Pfosser, P. M. Schluter, T. Fer, B.-Y. Sun, and H. Kato. 2006. Anagenetic evolution in island plants. Journal of Biogeography 33: 1259-1265.

Straub, S. C., M. Fishbein, T. Livshultz, Z. Foster, M. Parks, K. Weitemier, R. C. Cronn, and A. Liston. 2011. Building a model: Developing genomic resources for common milkweed (Asclepias syriaca) with low coverage genome sequencing. BMC Genomics 12: 211.

Sukumaran, J. and M. T. Holder. 2010. DendroPy: A Python library for phylogenetic computing. Bioinformatics 26: 1569-1571.

Sun, B.-Y. 2007. Pinaceae. In The genera of vascular plants of Korea, ed. C.-W. Park. Seoul: Academy Publishing Co.

Swofford, D. 2002. PAUP*: Phylogenetic Analysis Using Parsimony* (and other methods), v. 4.0 beta. Sunderland: Sinauer Associates.

Syring, J., A. Willyard, R. Cronn, and A. Liston. 2005. Evolutionary relationships among Pinus (Pinaceae) subsections inferred from multiple low-copy nuclear loci. American Journal of Botany 92: 2086-2100.

Syring, J., K. Farrell, R. Businský, R. Cronn, and A. Liston. 2007. Widespread genealogical nonmonophyly in species of Pinus Subgenus Strobus. Systematic Biology 56: 163-181.

Taylor, R. 1972. The relationship and origin of Tsuga heterophylla and Tsuga mertensiana based on phyotchemical and morphological interpretations. American Journal of Botany 59: 149-157. 
Tiffney, B. 1985. Perspectives on the origin of the floristic similarity between eastern Asia and eastern North America. Journal of the Arnold Arboretum 66: 73-94.

Tsutsui, K., A. Suwa, K. I. Sawada, T. Kato, T. A. Ohsawa, and Y. Watano. 2009. Incongruence among mitochondrial, chloroplast and nuclear gene trees in Pinus subgenus Strobus (Pinaceae). Journal of Plant Research 122: 509-521.

Tsuyama, I., K. Nakao, M. Higa, T. Matsui, K. Shichi, and N. Tanaka. 2014. What controls the distribution of the Japanese endemic hemlock, Tsuga diversifolia? Footprint of climate in the glacial period on current habitat occupancy. Journal of Forest Research 19: 154-165.

Vining, T. F. 1999. Molecular phylogenetics of Pinaceae. Ph.D. dissertation. Orono: University of Maine.

Wang, X.-Q. and J.-H. Ran. 2014. Evolution and biogeography of gymnosperms. Molecular Phylogenetics and Evolution 75: 24-40.

Wang, X.-Q., D. Tank, and T. Sang. 2000. Phylogeny and divergence times in Pinaceae: Evidence from three genomes. Molecular Biology and Evolution 17: 773-781.

Wang, X.-R and A. E. Szmidt. 1994. Hybridization and chloroplast DNA variation in a Pinus species complex from Asia. Evolution 48: 1020-1031.

Wei, X.-X. and X.-Q. Wang. 2004. Recolonization and radiation in Larix (Pinaceae): Evidence from nuclear ribosomal DNA paralogues. $\mathrm{Mo}$ lecular Ecology 13: 3115-3123.

Wei, X.-X., Z.-Y. Yang, Y. Li, and X.-Q. Wang. 2010. Molecular phylogeny and biogeography of Pseudotsuga (Pinaceae): Insights into the floristic relationship between Taiwan and its adjacent areas. Molecular Phylogenetics and Evolution 55: 776-785.

Willyard, A., R. Cronn, and A. Liston. 2009. Reticulate evolution and incomplete lineage sorting among the ponderosa pines. Molecular Phylogenetics and Evolution 52: 498-511.

Wilson, E. 1918. The vegetation of Korea. Transactions of the Korea Branch of the Royal Asiatic Society 9: 1-17.

Wu, C.-S., Y.-T. Lai, C.-P. Lin, Y.-N. Wang, and S.-M. Chaw. 2009. Evolution of reduced and compact chloroplast genomes (cpDNAs) in gnetophytes: Selection toward a lower-cost strategy. Molecular Phylogenetics and Evolution 52: 115-124.

Wyman, S., R. Jansen, and J. Boore. 2004. Automatic annotation of organellar genomes with DOGMA. Bioinformatics 20: 3252-3255.

Xiang, Q., Q. Xiang, Y. Guo, and X.-C. Zhang. 2009. Phylogeny of Abies (Pinaceae) inferred from nrITS sequence data. Taxon 58: 141-152.

Xiang, Q. P., R. Wei, Y.-Z. Shao, Z.-Y. Yang, X.-Q. Wang, and X.-C. Zhang. 2015. Phylogenetic relationships, possible ancient hybridization, and biogeographic history of Abies (Pinaceae) based on data from nuclear, plastid, and mitochondrial genomes. Molecular Phylogenetics and Evolution 82: 1-14.

Xing, Y.-W., Y. C. Liu, T. Su, F. M. B. Jacques, and Z.-K. Zhou. 2013. A new Tsuga species from the upper Miocene of Yunnan, southwestern China and its palaeogeographic significance. Palaeoworld 22: 159-167.

Zhang, S., W. Yang, S. Han, B. Han, and M. Li. 2010. Cytogenetic analysis of reciprocal hybrids and their parents between Larix leptolepis and Larix gmelinii: Implications for identifying hybrids. Tree Genetics $\mathcal{E}$ Genomes 6: 405-412.

Zwickl, D. J. 2006. Genetic algorithm approaches for the phylogenetic analysis of large biological sequence datasets under the maximum likelihood criterion. Ph.D. Dissertation. Austin: The University of Texas.

APPENDIX 1. List of accessions examined for species other than T. ulleungensis. GenBank accession numbers for specimens used in molecular analyses are indicated as: (cpDNA; $4 C L$ locus $1 ; 4 C L$ locus 2), and new sequences are in bold. Dash (-) indicates locus not sequenced for that specimen. Specimen information is organized by species, locality, date, collector, collection number (herbarium). Specimens from botanical gardens also include the garden, specimen number in cultivation, and wild collection locality, if known. Plants included in the common garden phenology study are noted as CG\#. AA = Arnold Arboretum; cult. = in cultivation; FHBG = Fay Hyland Botanical Garden, Orono, Maine; PDT = collected by Peter Del Tredici; USNA = United States National Arboretum.

Keteleeria davidiana (relevant publication: Wu et al. 2009), (NC011930; $-;-)$.

Nothotsuga longibracteata (relevant publication: Wang et al. 2000), (-;AF144523;-); CHINA. USNA 70160, cult., wild origin: Fujian Prov., voucher: Bentz SEB3 (NA)

(KX249803;-;-).
Tsuga canadensis UNITED STATES. FHBG, cult., wild origin: Maine, voucher: Holman 08-02 (AAH) (KX255640; KX354416; -); (relevant publication: Wang et al. 2000), (-; AF144525; AF144526).

Tsuga caroliniana UNITED STATES. FHBG, cult., wild origin: North Carolina, voucher: Holman 08-03 (AAH) (KX256180; KX354414; KX354415). AA705-93, cult., wild origin: North Carolina, voucher: Holman 09-50 (AAH) (-; KX354412; KX354413).

Tsuga chinensis CHINA. Anhui Prov.: Huangshan, 23 Oct 1933, W.C. Cheng 4594 (NA); Anhui Prov.: Huangshan, 12 Aug 1924, A.N. Steward 7194 (NA); Fujian Prov.: Wuyishan, 1,800 m, 1 Jan 1981, Y.-T. Zhang 2561 (NA); Guizhou Prov.: Yinjiang, Tongren, 840 m, 1931, W.C. Cheng 7972 (AAH); Hubei Prov.: Fangxian, Shiyan, 8,000-9,000ft, 1 May 1907, E.H. Wilson 5096 (AAH); AA 17569, cult., wild origin: Hubei Prov., voucher: Holman 09-72 (AAH) (-; KX354410; KX354411). Sichuan Prov.: Ziyang, 3 Aug 1989, QingSheng 207 (AAH); Sichuan Prov.: Lucheng, Kangding, N.E. of Tachienlu, 7,000-9,000 ft, 2 Jul 1908, E.H. Wilson 2100 (AAH); Sichuan Prov.: Lixian, Ching-Chi Hsien, 8,500 ft, 1 Aug 1908, E.H. Wilson 5097 (AAH); AA 2332003, cult., wild origin: Sichuan Prov., voucher: Holman 10-02 (AAH) (KX256181; KX354408; KX354409).

Tsuga chinensis TAIWAN. Chiayi County: Mt. Morrison, Kagi Prov., 2,500-3,833 m, 25 Oct 1918, E.H. Wilson 10904 (AAH).

Tsuga chinensis VIETNAM. Ha Giang Prov.: Ngan Chai, Ha Giang Prov., Yen Minh dist., 1,400m, 26 Nov 2004, S.K. Wu 705 (AAH).

Tsuga diversifolia JAPAN. Nagasaki Pref.: cult., wild origin unknown, 1863, Maximowicz (AAH); AA 17571A, cult., CG \#1, origin: Tokyo Pref.: Shinjuku, Imperial Botanical Garden, wild origin unknown, 1897, voucher: Holman 08-15 (AAH); AA 39-82A, cult., CG \#7, origin: 1982 cutting of AA 17571, Tokyo Pref.: Shinjuku, Imperial Botanical Garden, voucher: Holman 08-11 (AAH) (-; KX354406; KX354407); AA 1837-77A, cult., CG \#6, wild origin: Iwate Pref.: Iwanebashi, Mount Hayachine, subalpine zone, 16 Sep 1977, S.A. Spongberg 220 (AAH), voucher: Holman 08-11 (AAH) (-; KX374104; KX374105); Aomori Pref.: Mt. Hakkoda, 1,000m, 03 Oct 1892, C.S. Sargent (AAH); Fukushima Pref.: Takayu, 24 Jun 1904, Baurie 5747 (AAH); Fukushima Pref.: east slope of Mt. Higashiazuma, 1,700-1,975 m, 06 Jul 1984, H. Ohashi 11831 (AAH); Fukushima Pref.: Hinoemata, Ayamedaira, Oze, 20 Jun 1951, M. Mizushima 1195 (AAH); Fukushima Pref.: Tsuchiyuonsenmachi, Mt. Azuma, 05 Aug 1952, K. Uno 2612 (AAH); Gifu Pref.: Mino, Mt. Yenasam, 16 Aug 1910, Anonymous (NA); Gifu Pref.: Takayama, Norikura, 27 Jun 1955, H. Muroi 3852 (AAH); Gunma Pref.: Katashina, Konsei Pass, 2,000-2,020 m, 23 Aug 1982, T. Yahara 6350 (AAH); Iwate Pref.: Iwanebashi, Mt. Hayachine, Aionzawa, 1,000m, 08 Jul 1987, Tohda 2058 (AAH); Iwate Pref.: Rikuchukawai, Rikuchu, Mt. Hayachine, 1,000-2,000 m, 27 Sep 1915, E.H. Wilson 7557 (AAH); Nagano Pref.: Chino, Mt. Yatsugadake, 27 Sep 1986, R. Nicholson 1085-86 (AAH); Nagano Pref.: Matsumoto, Nakanoyu, Nagano, 26 Jul 1955, H. Muroi 3436 (AAH); Nagano Pref.: Sancho, Kurayu-yama, 1,300-1,900 m, 25 May 1977, E.W. Wood 3696 (AAH); Nara Pref.: Yamato, Shores of Lake Yamato, 05 Sep 1892, C.S. Sargent (AAH); Oita Pref.: Bungotaketa, Bungo: Mt. Sobo, 29 Aug 1911, E.H. Wilson 'Drugoi' (AAH); Tochigi Pref.: Shimotsukeosawa, Nikko region, 1,000-2,500 m, 16 Oct 1914, E.H. Wilson 7646 (AAH); Tokushima Pref.: Shikoku, Mt. Tsurugi, Gyoba, 1,700 m, 06 Jun 1984, T. Yamazaki 5271 (AAH); Yamagata Pref.: Akumi, Mt. Chokai, 14 Oct 1914, E.H. Wilson 7187 (AAH); Yamanashi Pref.: Minamitsuru, Minamitsuru-gun, Mt. Fuji, 11 Jun 1978, H. Ohba 78601 (AAH); Yamanashi Pref.: Oniwa, N.W. side of Mt. Fuji, 2,300 m, 15 Sep 1978, Y. Tateishi 15712 (AAH); AA 1146-86, cult., wild origin: Yamanashi Pref., voucher: Holman 09-71 (AAH) (KX256182; KX354404; KX354405).

Tsuga dumosa CHINA. Sichuan Prov.: Liangshan, Mountains of Kopati, Djago, and Muli, 2,900-3,535 m, 1 Jun 1928, J.F. Rock 16163 (NA); Yunnan Prov.: Yangbi, w. side of Diancang Shan mountain range, 3,000 m, 19 Jun 1984, B. Bartholomew 293 (AAH)

Tsuga dumosa MYANMAR. Kachin State: Jiangao Shan on trail E of Baduolin Yakou, 3,020m, 23 May 2006, L. Heng 30356 (GH).

Tsuga heterophylla UNITED STATES. Washington State: Clearwater National Forest, Palisades-White Pass. Peery 7-1 (KX256183;-;-).

Tsuga mertensiana (relevant publication: Wang et al. 2000), (-;AF144524;-).

Tsuga sieboldii JAPAN. USNA 55482-H, cult., wild origin: Mie Pref.: Ise City, Forest of Gegu Shrine, 1 Jan 1956, Creech, voucher: Bentz 13 (AAH); AA 1007-80A, cult., CG \#8, wild origin: Tochigi, Nikko, Japan, Tochigi Prefecture, Hosco, Nikko and Vicinity, 21 Aug 1980, voucher: Holman 09-09 (AAH) (KX256184; KX354398; KX354399); AA 1007-80B, cult., CG \#5, wild origin: Tochigi, Nikko, Japan, Tochigi Prefecture, Hosco, Nikko and Vicinity, 21 Aug 1980, voucher: Holman 08-17; AA 17577A, cult., CG \#2, wild origin unknown, Kyoto, Japan, Imperial Forest School, Japan, 20 Mar 1908, voucher: Holman 08-16 (AAH) (-; KX354400; KX354401); Aichi Pref.: Nagasuda, 1892, C.S. Sargent (AAH); Chiba Pref.: Amatsu, Tokyo Imperial University, Forest back of Amatsu, 7 Sep 1928, Beattie 10352 (NA); Chiba 
Pref.: Futtsu, Mt. Nokogiri, Nishitama-gun, 19 Mar 1953, M. Miyushima 11411 (AAH); Chiba Pref.: Kamogawa, Awa-gun, Mts. Kiyosumi, Yomogi, 200 m, 9 May 1976, Y. Tateishi 2317 (AAH); Gifu Pref.: Hida, 7 Aug 1933, K. Shiota 6685 (AAH); Gifu Pref.: Hida, 7 Aug 1933, K. Shiota 6746 (AAH); Gifu Pref.: Mino, 9 Aug 1933, K. Shiota 6790 (AAH); Hiroshima Pref.: Miyajima, 17 Apr 1903, Baurie 5349 (AAH); Hyogo Pref.: Fukuzaki, Hyogo Pref.: Mt. Nanakusa-yama, Kanzaki-gun, 200-300 m, 26 May 1979, S. Tsugaru 5375 (AAH); Kagoshima Pref.: Yakushima, Kumage-gun, Yaku-cho, Yugo forestry road to Mt. Shichigo, 880-1,488 m, 30 Jul 1992, S. Kobayashi 1731 (AAH); Kagoshima Pref.: Yakushima, 500-1,150 m, 21 Feb 1914, E.H. Wilson 6037 (AAH); Kanagawa Pref.: Nakahara, Japonia. Yokohama, 1862, Maximowicz (NA); Kishi Pref.: Koya, 1,000m, 2 Dec 1914, E.H. Wilson 7845 (AAH); Kyoto Pref.: Hiyoshi, Kbidani, Yotsuya, Funai-gun, 650m, 5 Jul 1995, S. Tsugaru 22360 (AAH); Kyoto Pref.: Kameoka, Fudo-SagaKameoka-sen, Hodzu-cho, Kameoka-shi, 24 Jun 2001, S. Tsugaru 30684 (AAH); Kyoto Pref.: Keihoku, near Koshiki-toge, Kitakuwada-gun, 780m, 6 Jul 1995, T. Takahashi 2861 (AAH); Kyoto Pref.: Keihoku, Hattyo-rindo, Kitakuwada-gun, 490 m, 17 Sep 1994, S. Tsugaru 20940 (AAH); Kyoto Pref.: Nantan, Hiyashi, Kyushu, 3 Aug 1914, E.H. Wilson 6221 (AAH); Nagano Pref.: Nagawa, Minami-azumi-gun, Nyuyamaguchi, 900 m, 6 Jun 1983, T. Yahara 6946 (AAH); Nagano Pref.: Shimoina, Urugi, 13 Jun 1957, Yamazaki 3794 (AAH); Nara Pref.: Wakakusayama, 310 m, 18 May 2008, PDT 15-11 (AAH); Nara Pref.: Wakakusayama, 310m, 18 May 2008, PDT 15-12 (AAH); Osaka Pref.: Kawachinagano, Iwawaki-san, 570 m, 8 Jun 2004, N. Havill 0430 (GH); Osaka Pref.: Takatsuki, Myo-on-ji Temple, 375-400 m, 17 May 2008, PDT 13-8 (AAH); Osaka Pref.: Takatsuki, Myo-on-ji Temple,
375-400 m, 17 May 2008, PDT 13-9 (AAH); Osaka Pref.: Takatsuki, Nakahata, 370m, 9 Jun 2004, N. Havill 04-34 (GH); Osaka Pref.: Toyono, Yoshikawa, Toyono-cho, 180 m, 9 Jun 2004, N. Havill 04-33 (GH); Tosa Pref.: Motoyama, Shikoku, Shiraga, 1,000-1,600 m, 22 Nov 1914, E.H. Wilson 7791A (AAH); Tosa Pref.: Shikoku, 500-1,000 m, 19 Nov 1914, E.H. Wilson 7791 (AAH); Wakayama Pref.: Kogawa, Tomisato, Oto-mura, Nishimurogun., 500 m, 11 Aug 1965, G. Murata (AAH); Wakayama Pref.: Koya, Kongo-buji Temple, Koya-cho, 820 m, 8 Jun 2004, N. Havill 04-31 (GH); Wakayama Pref.: Koya, Mt. Benten, Koya-san, 920 m, 8 Jun 2004, N. Havill 04-32 (GH).

ApPendix 2. Third-generation DNA sequencing metrics.

\begin{tabular}{llcrrr}
\hline \hline \multicolumn{1}{c}{ Species } & Barcode & Contigs & $\begin{array}{c}\text { Read } \\
\text { Length }\end{array}$ & \multicolumn{1}{c}{ Reads } & Coverage \\
\hline $\begin{array}{l}\text { Nothotsuga } \\
\quad \text { longibracteata }\end{array}$ & CGTT & 27 & 33 & $2,411,734$ & 676 \\
Tsuga canadensis & GATT & 93 & 33 & 350,266 & 98 \\
Tsuga caroliniana & CACTCA & 23 & 100 & $2,651,733$ & 2,253 \\
Tsuga chinensis & ACGT & 38 & 80 & 952,434 & 647 \\
Tsuga diversifolia & CTGT & 31 & 80 & $1,734,013$ & 1,178 \\
Tsuga heterophylla & AACT & 61 & 50 & $1,855,346$ & 788 \\
Tsuga sieboldii & GATT & 44 & 80 & $1,808,736$ & 1,229 \\
Tsuga ulleungensis & TCAT & 30 & 80 & $1,726,604$ & 1,173 \\
\hline
\end{tabular}

